\title{
43. DOWN-HOLE TEMPERATURE MEASUREMENTS, DEEP SEA DRILLING PROJECT, LEG 42A
}

\author{
Albert J. Erickson, Geology Department, University of Georgia, Athens, Georgia \\ and \\ Richard P. Von Herzen, Department of Geology and Geophysics, Woods Hole Oceanographic Institution, \\ Woods Hole, Massachusetts
}

\begin{abstract}
Heat-flow measurements were made in DSDP boreholes at five sites in the Mediterranean and Aegean seas. Abnormallly high heat flow was observed in the Algero-Provençal Basin, and in the Tyrrhenian and Aegean seas. Much lower heat flow was observed through the Central Ionian Sea and on the Florence Rise southwest of Cyprus. The heat-flow data from the DSDP holes are in excellent agreement with nearby conventional heat-flow values. High heat-flow through the Tyrrhenian and Aegean seas suggests, but does not require, that these basins are back-arc basins associated with the Calabrian and Cretan island arcs. The explanation of high heat flow through the Algero-Provençal and Balearic basins, and of low heat flow through the entire eastern Mediterranean Sea, may be related to thermal and chemical differences in, and horizontal and/or vertical displacements of, the asthenosphere beneath the converging African and Eurasian plates.
\end{abstract}

\section{INTRODUCTION}

The origin of small ocean basins, whether residual fragments of ancient oceans or newly formed by still poorly understood geological processes, is a major unsolved geophysical problem. Theories proposed for the origin of the eastern and western Mediterranean and Aegean seas are varied, but all are ultimately dependent upon thermal energy to provide the uplift, warping, subsidence, or rifting called upon by various investigators. Knowledge of the temperature distribution beneath the Mediterranean and Aegean seas provides an important constraint on models for the formation of these basins.

Seasonal changes in bottom water temperatures are capable of significantly altering the thermal gradient in the sediment to depths of about 10 meters below the sea floor. The Mediterranean and Aegean seas, primarily because of their relatively shallow depths and limited volumes, are considerably more susceptible to seasonal and longer period changes in bottom water temperature than the deep ocean basins. Longer period variations (for example, those resulting from glacial and interglacial events which last on the order of $10^{4}$ to $10^{5}$ years) can be significant hundreds of meters below the sea floor, depending upon their duration and amplitude.

Conventional heat-flow measurements made from oceanographic vessels generally only measure the thermal gradient in the uppermost 10 meters of sediment beneath the sea floor, where both seasonal and longer term effects may be important. For this reason, the geophysical interpretation of conventional heatflow measurements in the Mediterranean and the Aegean seas has been subject to some doubt because the history, and therefore the effect, of bottom water temperature variations is poorly understood. One way to eliminate changes introduced by seasonal bottom water temperature variations is to measure temperatures in sediment far below the depth to which annual temperature variations penetrate. This opportunity was provided by measurements of sediment temperatures in the holes drilled during Leg $42 \mathrm{~A}$.

\section{PREVIOUS GEOTHERMAL STUDIES}

Only a few isolated heat-flow measurements reported upon by Bullard and Day (1961), Lister (1963), Nason and Lee (1964), and Birch and Halunen (1966) were taken in the Mediterranean and Aegean seas before 1970. Since that time many additional marine heat-flow measurements have been made in both the eastern and western Mediterranean by Ryan (1969), Erickson (1970), and Haenel (1972). Jongsma (1974) and Lavenia (1967) obtained heatflow data in the Aegean and Adriatic seas, respectively. Morgan (in press) determined heat-flow values using temperatures measured in holes on Cyprus.

The overall picture that emerges is strikingly simple. Heat-flow values in the western Mediterranean as a whole tend to be above normal (see Table 1), with the highest (and most variable values) observed in the Tyrrhenian Sea. The pattern of high heat flow in the western Mediterranean is in sharp contrast to lower and less variable heat-flow values in the eastern Medi- 
TABLE 1

Summary of Marine Heat Flow Data in the Mediterranean, Aegean, and Adriatic Seas ${ }^{\mathrm{a}}$

\begin{tabular}{|c|c|c|c|c|}
\hline \multirow[b]{2}{*}{ Region } & \multirow{2}{*}{$\begin{array}{l}\text { Number of } \\
\text { Measure- } \\
\text { ments }\end{array}$} & \multicolumn{2}{|c|}{$\begin{array}{l}\text { Observed Heat Flow } \\
\left(\mu \mathrm{cal} / \mathrm{cm}^{2} \mathrm{sec}\right)\end{array}$} & \multirow[b]{2}{*}{ Reference } \\
\hline & & Average & $\begin{array}{l}\text { Stand. } \\
\text { Dev. }\end{array}$ & \\
\hline \multicolumn{5}{|l|}{ Aegean Sea } \\
\hline Northern and Central & 9 & 2.08 & 0.24 & Jongsma (1974) \\
\hline Southern & 4 & 1.01 to 1.64 & - & Jongsma (1974) \\
\hline Adriatic Sea & 11 & 1.32 & 0.34 & Lavenia (1967) \\
\hline Eastern Mediterranean & 33 & 0.74 & 0.30 & Erickson (1970) \\
\hline Ionian Sea & 4 & 1.23 & 0.14 & Haenel (1972) \\
\hline \multicolumn{5}{|l|}{ Western Mediterranean } \\
\hline Tyrrhenian Sea & 12 & 2.83 & 1.07 & Erickson (1970) \\
\hline $\begin{array}{l}\text { West of Sardinia } \\
\text { and Corsica }\end{array}$ & 12 & 1.83 & 0.55 & Erickson (1970) \\
\hline
\end{tabular}

all data were obtained using conventional oceanographic heat probes and have not been corrected for environmental effects.

terranean. Terrestrial heat-flow measurements on $\mathrm{Cy}$ prus (Morgan, in press) are in excellent agreement with the surrounding sea-bottom values.

Heat-flow values in the Adriatic Sea are generally near the global average, with higher values measured near the boundaries of the southern basin. Measurements in the Aegean are above normal and tend to be higher in the northern and central Aegean than in the southern part, where non-linear gradients were recorded. Both the Adriatic and Aegean seas are known to be seasonal sources of cold bottom water for the eastern Mediterranean (Miller, 1972) and thus are areas where shallow heat-flow measurements may have been affected by temperature variations of the bottom water.

\section{EQUIPMENT AND MEASUREMENT TECHNIQUES}

The temperature measurements were made with an entirely self-contained down-hole temperature instrument (DTI) designed to fit in the bottom of a standard wire-line core barrel (Erickson et al., 1975). Temperature was measured every 8 seconds for about $1-1 / 2$ hours, and the data were stored digitally on magnetic tape in the instrument. Data playback was accomplished onboard ship with the use of either a computer or tables to convert the digital data stored on the magnetic tape to down-hole temperatures.

After drilling to the depth where a temperature measurement was desired, the bit was raised off the sea floor and a modified core barrel containing the DTI was lowered on the wireline to the bottom of the drill string. Once the core barrel was latched into the bottom-hole assembly the drill string was lowered slowly to the bottom of the previously drilled hole. The thermistor probe was then pushed about 30 to $50 \mathrm{~cm}$ into the undrillled sediment where it was left, with a minimum of disturbance, for 15 minutes to approach thermal equilibrium with the sediment. Following the measurement the bit was raised a few meters above the bottom of the hole and the core barrel was retrieved with the wire line. Because of the low thermal diffusivity of sediment, the thermal effects of drilling do not penetrate more than 5 or $10 \mathrm{~cm}$ below the bottom of the hole in the time (usually about 1 to 2 hours) from cessation of drilling until the temperature probe is emplaced. Thus the temperatures measured in the sediment are, in most cases, representative of the in situ sediment temperature.

Whenever possible, the same DTI and thermistor combination was used for all of the measurements at a particular site. In the few instances when this was not feasible, a comparison was made between the minimum temperature recorded as the temperature probe traversed the drill pipe, and the temperature recorded immediately before and after the probe entered and left the subbottom portion of the drill pipe for all of the temperature measurements at a given site. Since the geometry of all the temperature probes was identi$\mathrm{cal}$, and the lowering procedures were the same, we assume that all combinations of probes and instruments should record nearly the same temperatures while in transit through the lower portion of the drill pipe at a given site. When a systematic difference was noted between temperatures recorded by two different measuring systems at one site, a correction was made to all the temperatures recorded by one instrument to bring the water temperature data obtained by both instruments into closer correspondence. The size of the correction (if any) is indicated in Table 2. In all cases the size of the correction is small compared to the temperature differences measured in the hole.

Although the precision and accuracy of the down hole temperature system are $0.01^{\circ} \mathrm{C}$ and $0.10^{\circ} \mathrm{C}$, respectively, the actual error in estimating the in situ sediment temperature may be much larger, and, in

TABLE 2

Summary of Down-Hole Temperature Data Obtained During Leg 42A in the Mediterranean and Aegean Seas ${ }^{\mathrm{a}}$

\begin{tabular}{|c|c|c|c|c|c|}
\hline $\begin{array}{l}\text { Temp. } \\
\text { Meas. }\end{array}$ & Hole & $\begin{array}{l}\text { Subbottom } \\
\text { Depth (m) }\end{array}$ & $\begin{array}{l}\text { Sediment } \\
\text { Temp. }\left({ }^{\circ} \mathrm{C}\right)\end{array}$ & $\begin{array}{l}\text { Correction } \\
\left.\text { Applied ( }{ }^{\circ} \mathrm{C}\right)\end{array}$ & Data Quality \\
\hline & $372 \mathrm{~A}$ & $0.0 \pm 2$ & $12.86 \pm 0.05^{b}$ & 0 & \\
\hline 1 & $372 \mathrm{~A}$ & $105.0 \pm 1$ & $20.80 \pm 0.02$ & 0 & Excellent \\
\hline 2 & $372 \mathrm{~A}$ & $125.0 \pm 1$ & $22.28 \pm 0.02$ & 0 & Excellent \\
\hline 3 & $372 \mathrm{~A}$ & $145.0 \pm 1$ & $23.84 \pm 0.02$ & 0 & Excellent \\
\hline \multirow[t]{2}{*}{4} & $372 \mathrm{~A}$ & $155.0 \pm 1$ & $24.40 \pm 0.02$ & 0 & Excellent \\
\hline & $373 \mathrm{~A}$ & $0.0 \pm 2$ & $13.07 \pm 0.05^{b}$ & 0 & \\
\hline 5 & $373 \mathrm{~A}$ & $106.0 \pm 1$ & $21.88 \pm 0.02$ & 0 & Excellent \\
\hline 6 & $\begin{array}{l}373 \mathrm{~A} \\
374\end{array}$ & $\begin{aligned} 125.0 & \pm 1 \\
0.0 & \pm 2\end{aligned}$ & $\begin{array}{l}22.38 \pm 0.02 \\
13.37 \pm 0.05^{b}\end{array}$ & $\begin{array}{c}-0.12 \\
0\end{array}$ & Excellent \\
\hline 7 & 374 & $109.0 \pm 1$ & $16.92 \pm 0.20$ & 0 & $\begin{array}{l}\text { Slow temp. rise after initial } \\
\text { decay of frictional heat }\end{array}$ \\
\hline 8 & 374 & $161.5 \pm 1$ & $18.37 \pm 0.03$ & 0 & Excellent \\
\hline 9 & 374 & $209.0 \pm 1$ & $19.61 \pm 0.02$ & 0 & Excellent \\
\hline 10 & 374 & $256.5 \pm 1$ & $20.76 \pm 0.02$ & 0 & Excellent \\
\hline \multirow[t]{2}{*}{11} & 374 & $304.0 \pm 1$ & $22.08 \pm 0.02$ & 0 & Excellent \\
\hline & 376 & $0.0 \pm 2$ & $13.05 \pm 0.05^{b}$ & 0 & \\
\hline 12 & 376 & $26.5 \pm 1$ & $13.66 \pm 0.02$ & 0 & Excellent \\
\hline 13 & 376 & $55.0 \pm 1$ & $14.92 \pm 0.04$ & 0 & $\begin{array}{l}\text { Equilibrium estimated due } \\
\text { to very rapid cooling }\end{array}$ \\
\hline 14 & 376 & $74.0 \pm 1$ & $15.50 \pm 0.20$ & 0 & $\begin{array}{l}\text { Disturbed, equilibrium } \\
\text { curve inadequate for accu- } \\
\text { rate extrapolation }\end{array}$ \\
\hline 15 & 376 & $102.5 \pm 1$ & $15.62 \pm 0.02$ & 0 & Excellent (see Figure 1o) \\
\hline \multirow[t]{2}{*}{16} & 376 & $131.0 \pm 1$ & $14.98 \pm 0.50$ & 0 & $\begin{array}{l}\text { Slow temp. rise after initial } \\
\text { decay of frictional heating } \\
\text { (see Figure 1p) }\end{array}$ \\
\hline & 378 & $0.0 \pm 2$ & $14.10 \pm 0.05^{b}$ & & \\
\hline 17 & 378 & $122.0 \pm 1$ & $23.07 \pm 0.10$ & 0 & $\begin{array}{l}\text { Increasingly rapid decrease } \\
\text { following penetration. } \\
\text { Chose max. temp (see Fig- } \\
\text { ure 1q) }\end{array}$ \\
\hline 18 & 378 & $226.5 \pm 1$ & $31.75 \pm 0.02$ & +0.08 & Excellent \\
\hline 19 & $378 \mathrm{~A}$ & $302.5 \pm 1$ & $34.88 \pm 0.03$ & 0 & $\begin{array}{l}\text { Excellent, slowly cooling } \\
\text { during measurement peri- } \\
\text { od (see Figure 1s) }\end{array}$ \\
\hline
\end{tabular}

${ }^{\text {a See text for discussion of measurement techniques and estimates of probable errot and }}$ reliability.

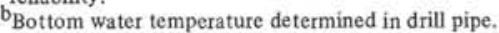


some cases, difficult to estimate. The main source of uncertainty is whether or not the material in which the temperature probe is immersed is at in situ sediment temperature. If sediment sloughs off the walls of the hole and fills the bottom of the hole, it will have a lower temperature than the undrilled sediments beneath the hole. Depending upon the physical properties and quantity of the sloughed sediment, an erroneously low (but accurate) bottom-hole temperature measurement may be obtained in the slumped sediment rather than in the undrilled sediments ahead of the drill bit. Other problems may arise if the undrilled sediment is either too hard for the probe to fully penetrate or else is penetrated in such a way that cool water from the hole flows down along the probe to cool the tip. Whichever occurs, the observed sediment temperature will be lower than the actual in situ sediment temperature. If the bottom-hole assembly containing the temperature probe moves vertically because of ship motion, the temperature measurement will be periodically or intermittently disturbed by frictional heating as the probe is reinserted in, or prematurely withdrawn from, the bottom of the hole during the temperature measurement. If the motion has sufficient amplitude to pull the probe entirely out of the sediment into the mixture of seawater and sediment at the bottom of the hole, the disturbance will be even more marked. In such a case, the observed temperature may only provide a very rough estimate or set wide limits on the in situ sediment temperatures.

Careful attention to events occurring on the drill rig floor during the temperature measurement and experience in interpreting numerous downhole temperature records greatly aid in evaluating the reliability of individual downhole temperature measurements. But we must admit that the possible temperature errors are much larger than the nearly negligible instrumental errors, and are in many cases highly subjective. Temperature-time plots obtained during each down-hole temperature measurement are shown in Figures 1a through ls to permit the reader to make his own reliability estimate.

In order to calculate the rate of heat flow (energy flux) through the interval over which the geothermal gradient is determined, we need to know the thermal conductivity of the sediment in that interval. Thermal conductivity was measured onboard ship by the transient needle-probe technique (Von Herzen and Maxwell, 1959). Thermal conductivity values are believed to have an accuracy of better than $\pm 10 \%$, as verified onboard ship by measurements made on conductivity standards. The thermal conductivity data obtained at each drill site during Leg $42 \mathrm{~A}$ are discussed in the corresponding Site Reports (this volume) and are tabulated in Appendix VI (this volume). These values must be corrected for temperature and pressure conditions in the hole in order to be of use in the calculation of the rate of heat flow through the sediments. We accomplished this by the application of correction factors proposed by Ratcliffe (1960), and modified for use in deep-sea holes (Erickson, 1973).
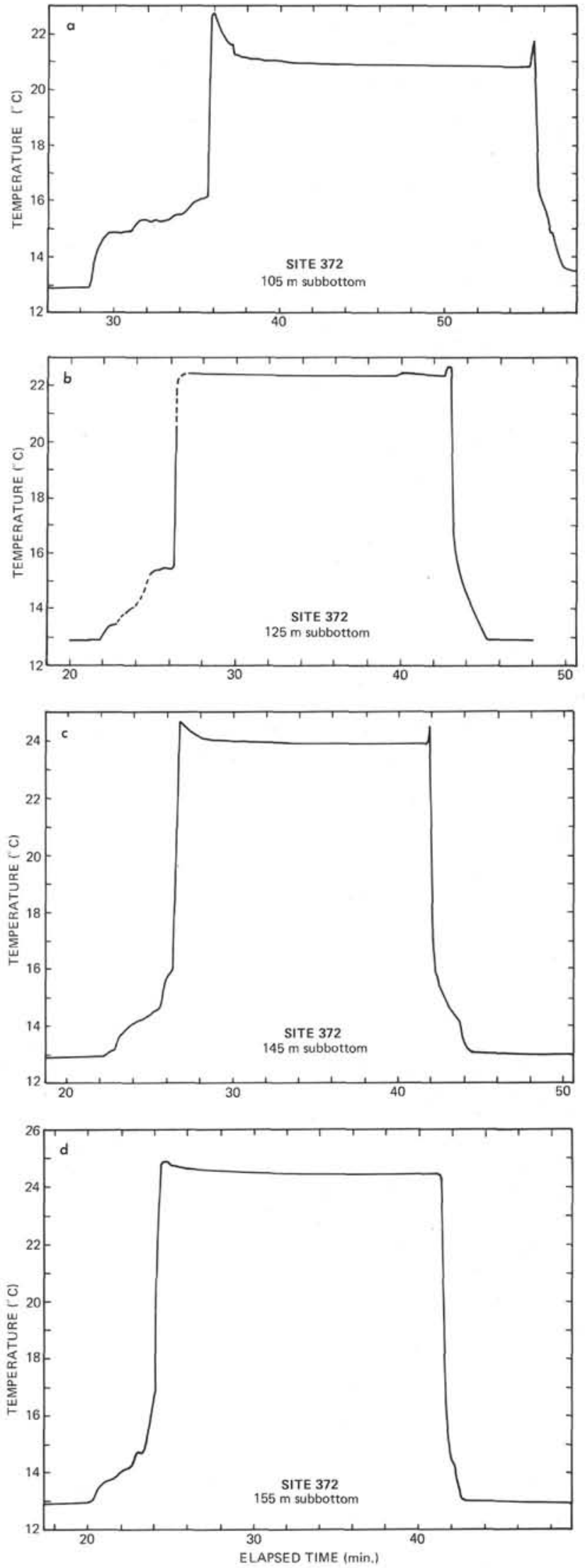

Figure 1. Plot of temperature as a function of time at Sites $372,373,374,376$, and 378 during downhole temperature measurements. 

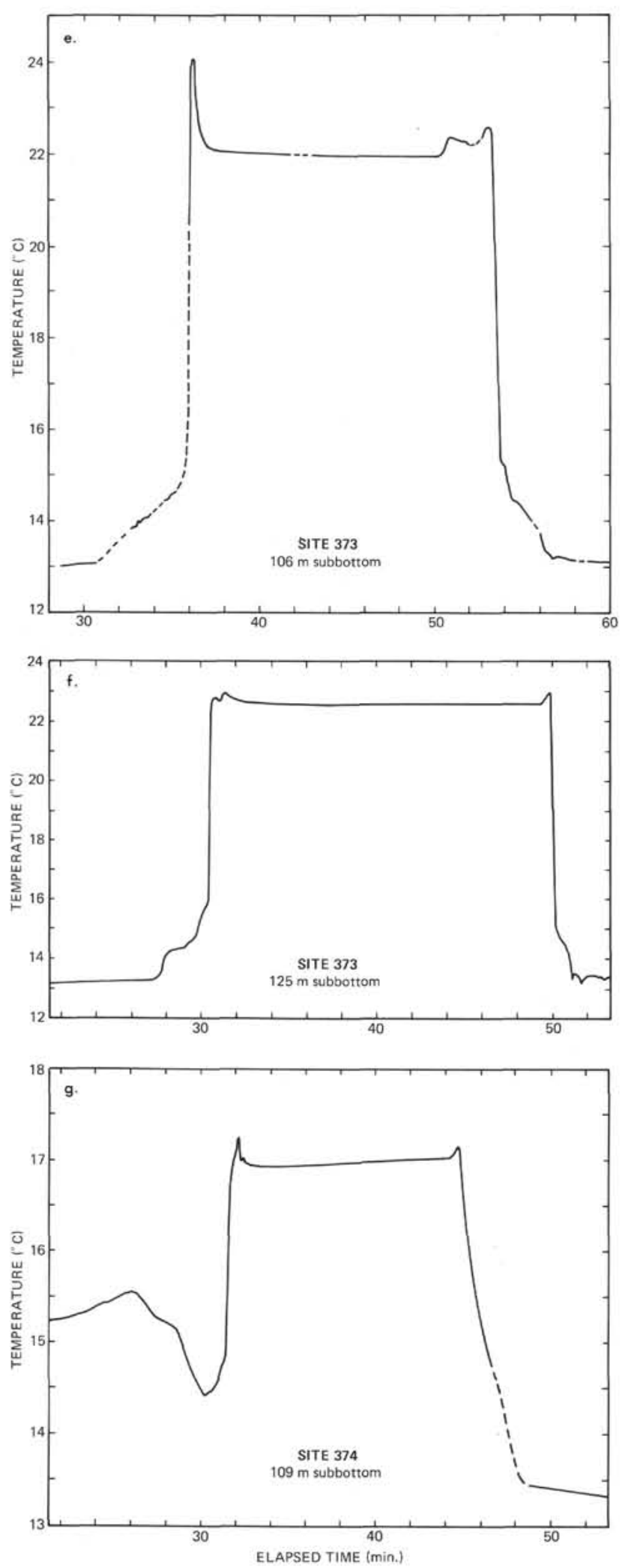

Figure 1. (Continued).

\section{RESULTS}

Site 372

Site 372 is in the Algero-Provençal Basin in the western Mediterranean on the base of the East Me-
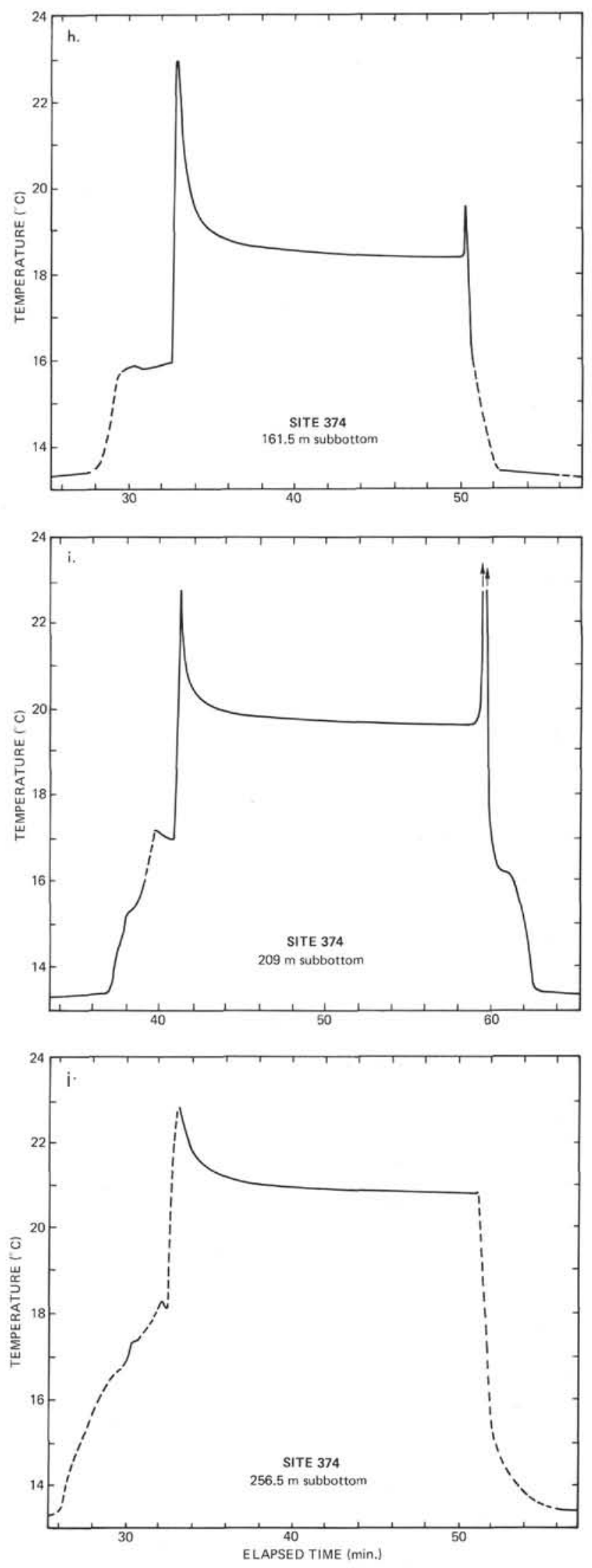

Figure 1.(Continued).

norca Rise in 2699 meters of water (Figure 2). Two holes were drilled, the second (Hole 372A) was offset 

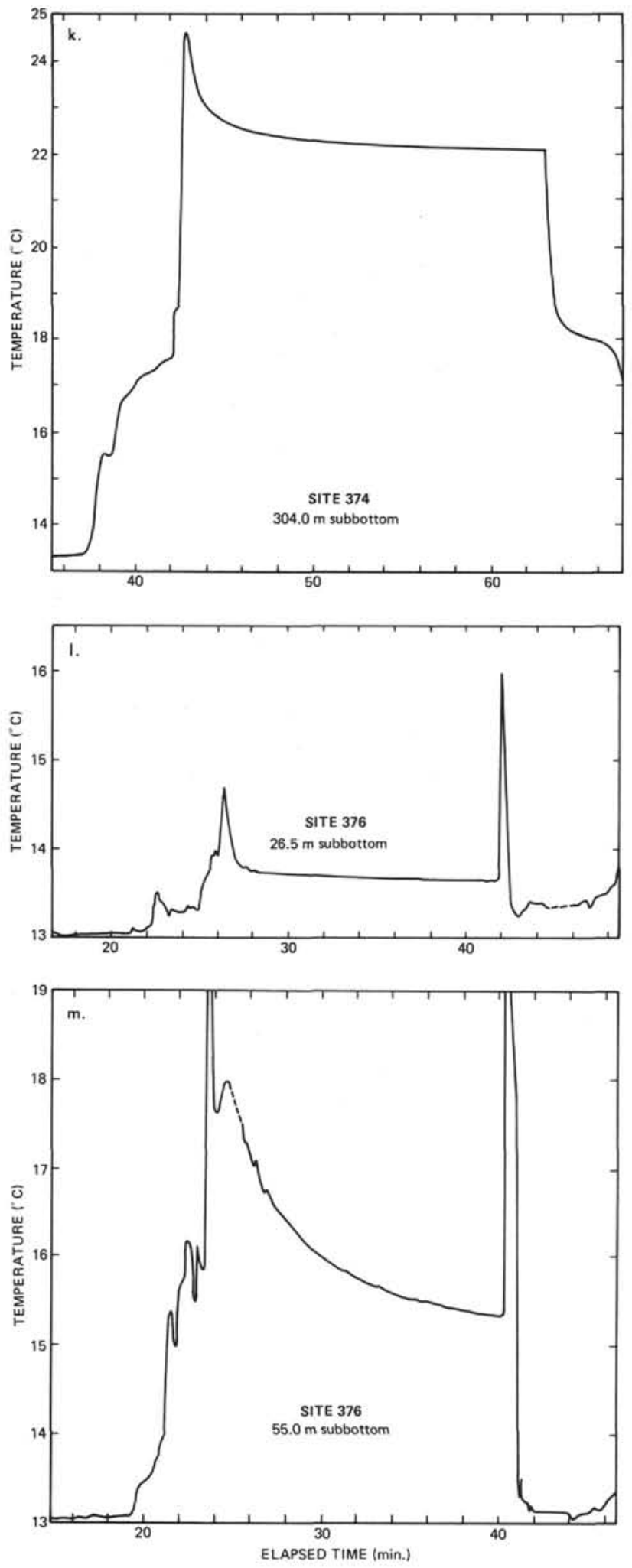

Figure 1. (Continued).

impenetrable clay, permitted us to record four excellent down-hole temperature measurements at Hole $372 \mathrm{~A}$. The best estimates of the in situ sediment temperature 500 meters east of the first hole, Hole 372, for the measurement of down-hole temperatures. Very calm seas and the presence of homogeneous, firm, but not
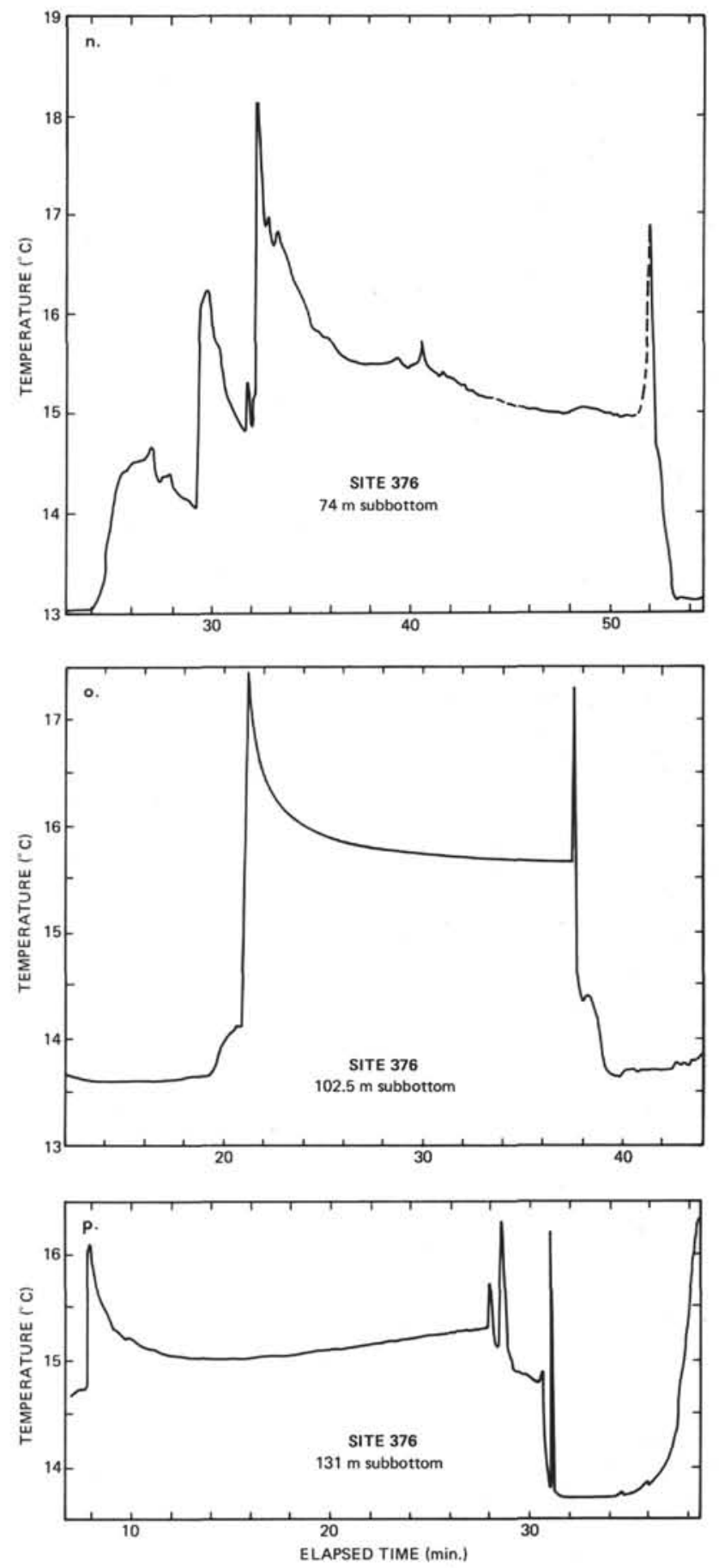

Figure 1.(Continued).

for each of the four measurements is plotted versus subbottom depth in Figure 3 and are listed in Table 2. Water temperature immediately above the sea floor was estimated at $12.86^{\circ} \mathrm{C}$ from the temperature observed just before the temperature probe passed into the subbottom portion of the drill string.

The mean thermal gradient in the three intervals from the sea floor down to and including temperature data acquired at 145.0 meters is $75.9^{\circ} \mathrm{C} / \mathrm{km}$ with a standard deviation of only $2.0^{\circ} \mathrm{C} / \mathrm{km}$ (Table 3 ). A lower gradient of $56.0 \pm 9.6^{\circ} \mathrm{C} / \mathrm{km}$ was calculated. between 145.0 and 155.0 meters subbottom. The low- 

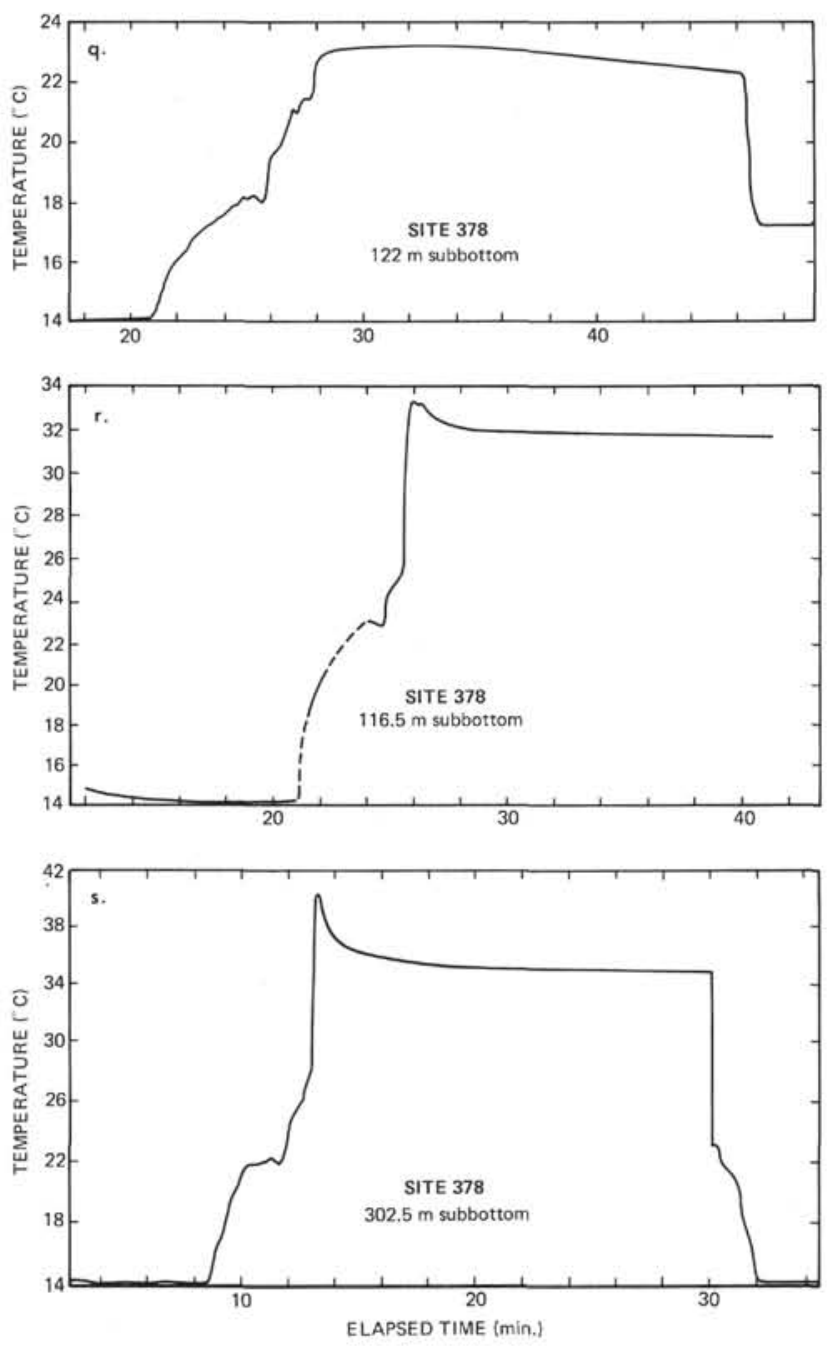

Figure 1. (Continued).

ermost temperature measurement may have been affected by the presence of a highly conductive sand layer immediately adjacent to a thin gypsum-anhydrite sequence; possibly the temperature measurement was in or below the evaporite layer itself. For this reason

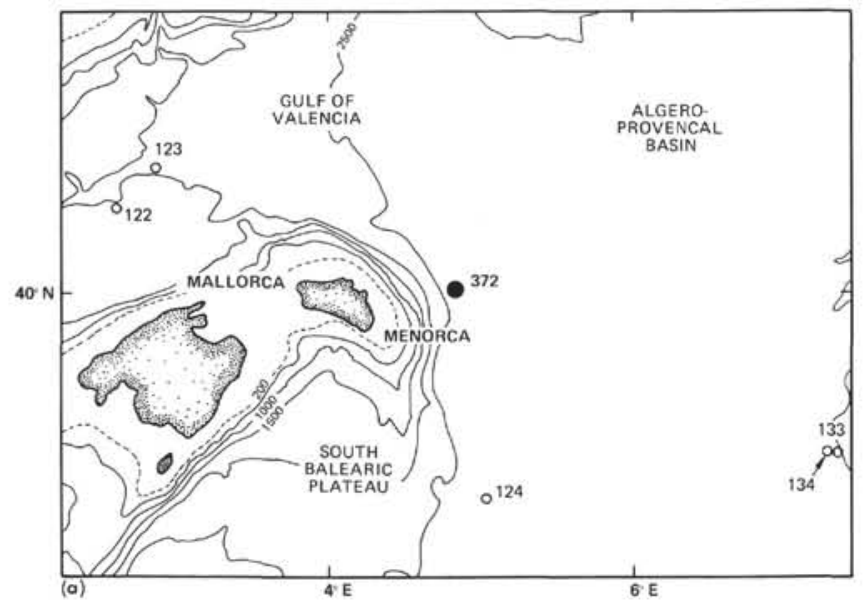

Figure 2. Location of Site 372 in the Algero-Provençal basin.

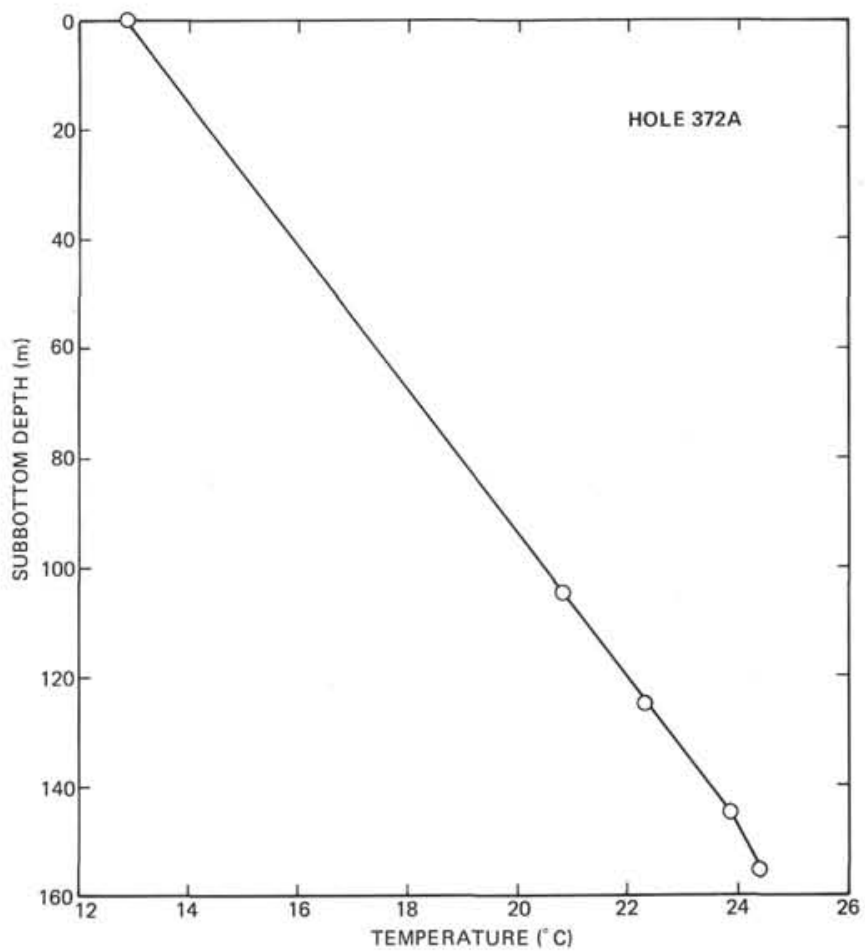

Figure 3. Plot of sediment temperature versus subbottom depth in Hole $372 \mathrm{~A}$.

the lowermost gradient was not used in the heat-flow calculations at this site. Multiplication of the average thermal gradient above 145.0 meters subbottom by the harmonic mean of the thermal conductivity measurements made on sediments recovered between 115.2 and 144.2 meters at Hole 372,500 meters westsouthwest of Hole 372A, gives a mean heat flow of $2.45 \times 10^{-6} \mathrm{cal} / \mathrm{cm}^{2} \mathrm{sec}$ at this site. This value is in good agreement with other western Mediterranean heat-flow measurements obtained nearby in the Balearic Basin (Erickson, 1970), and is about 1.5 times the mean global heat flux, which substantiates previous conclusions on the basis of conventional oceanographic heat-flow determinations that the western Mediterranean is characterized by above-normal heat flow.

\section{Site 373}

Site 373 was located in 3517 meters of water on the flank of a basaltic seamount in the central Tyrrhenian Abyssal Plain (Figure 4). Approximately 370 meters of sediment were penetrated before drilling penetrated into basaltic breccias. Down-hole temperatures were measured at 106 and 125 meters subbottom (Figure $5)$. These two well-recorded temperature measurements, plus an estimate of bottom water temperature recorded as the temperature probe passed through the drill pipe, were used to calculate two interval thermal gradients at this site (Table 3 ).

Heat flow at the site is best represented by the product of the average of the geothermal gradients measured between the sea floor and 106 and 125 meters, and the mean of three thermal conductivity measurements corrected for hole temperature and 
TABLE 3

Interval Heat-Flow Values Calculated From Down-Hole Temperature Measurements and Thermal Conductivity Data Obtained During DSDP Leg $42 \mathrm{~A}^{\mathrm{a}}$

\begin{tabular}{|c|c|c|c|c|c|}
\hline \multirow{2}{*}{$\begin{array}{l}\text { Subbot- } \\
\text { tom In- } \\
\text { terval (m) }\end{array}$} & \multirow{2}{*}{$\begin{array}{l}\text { Temperature } \\
\text { Difference } \\
\left({ }^{\circ} \mathrm{C}\right)\end{array}$} & \multirow{2}{*}{$\begin{array}{l}\text { Thermal } \\
\text { Gradient } \\
\left({ }^{\circ} \mathrm{C} / \mathrm{km}\right)\end{array}$} & \multicolumn{2}{|c|}{$\begin{array}{l}\text { Thermal Conductivity } \\
\left(\mathrm{mcal} / \mathrm{cm} \mathrm{sec}^{\circ} \mathrm{C}\right)\end{array}$} & \multirow{2}{*}{$\begin{array}{c}\text { Heat Flow } \\
\mu \mathrm{cal} /\left(\mathrm{cm}^{2} \mathrm{sec}\right)\end{array}$} \\
\hline & & & Observed & Corrected & \\
\hline \multicolumn{6}{|l|}{ Site 372} \\
\hline $0.0-105.0$ & $7.94 \pm 0.07$ & $75.6 \pm 2.1$ & $(3.10)$ & 3.12 & 2.36 \\
\hline $105.0-125.0$ & $1.48 \pm 0.04$ & $74.0 \pm 5.7$ & 3.10 & 3.15 & 2.33 \\
\hline $125.0-145.0$ & $1.56 \pm 0.04$ & $78.0 \pm 5.9$ & 3.21 & 3.27 & 2.55 \\
\hline $145.0-155.0$ & $0.56 \pm 0.04$ & $56.0 \pm 9.6$ & 3.35 & 3.42 & 1.92 \\
\hline \multicolumn{6}{|l|}{ Site 373} \\
\hline $0.0-106.0$ & $8.81 \pm 0.07$ & $83.1 \pm 2.2$ & 2.14 & 2.15 & 1.78 \\
\hline $106.0-125.0$ & $0.50 \pm 0.04$ & $26.3 \pm 3.5$ & $(2.14)$ & 2.19 & 0.58 \\
\hline \multicolumn{6}{|l|}{ Site 374} \\
\hline $0.0-109.0$ & $3.55 \pm 0.25$ & $32.5 \pm 2.9$ & 2.92 & 2.94 & 0.96 \\
\hline $109.0-161.5$ & $1.45 \pm 0.03$ & $27.6 \pm 1.1$ & 2.76 & 2.80 & 0.77 \\
\hline $161.5-209.0$ & $1.24 \pm 0.05$ & $26.1 \neq 1.6$ & $(2.90)$ & 2.95 & 0.77 \\
\hline $209.0-256.5$ & $1.15 \pm 0.04$ & $24.2 \pm 1.4$ & 3.22 & 3.29 & 0.80 \\
\hline $256.5-304.0$ & $1.32 \pm 0.04$ & $27.8 \pm 1.4$ & 3.17 & 3.25 & 0.90 \\
\hline \multicolumn{6}{|l|}{ Site 376} \\
\hline $0.0-26.5$ & $0.61 \pm 0.07$ & $23.0 \pm 4.4$ & 2.51 & 2.48 & 0.57 \\
\hline $26.5-55.0$ & $1.26 \pm 0.06$ & $44.2 \pm 3.7$ & 2.84 & 2.82 & 1.25 \\
\hline $55.0-74.0$ & $0.58 \pm 0.24$ & $30.5 \pm 14.2$ & 2.83 & 2.81 & 0.86 \\
\hline $74.0-102.5$ & $0.12 \pm 0.22$ & $4.2 \pm 7.8$ & 3.04 & 3.03 & 0.13 \\
\hline $102.5-131.0$ & $-0.64 \pm 0.62$ & $-22.5 \pm 22.6$ & 2.98 & 2.97 & -0.67 \\
\hline \multicolumn{6}{|l|}{ Site 378} \\
\hline $0.0-122.0$ & $8.97 \pm 0.15$ & $73.5 \pm 2.43$ & 2.75 & 2.76 & 2.03 \\
\hline $122.0-226.5$ & $8.67 \pm 0.12$ & $83.0 \pm 1.94$ & 2.69 & 2.76 & 2.29 \\
\hline $226.5-302.5$ & $3.13 \pm 0.05$ & $41.2 \pm 1.20$ & (2.69) & 2.80 & 1.15 \\
\hline
\end{tabular}

${ }^{a}$ Conductivity values in parentheses are estimated from adjacent intervals.

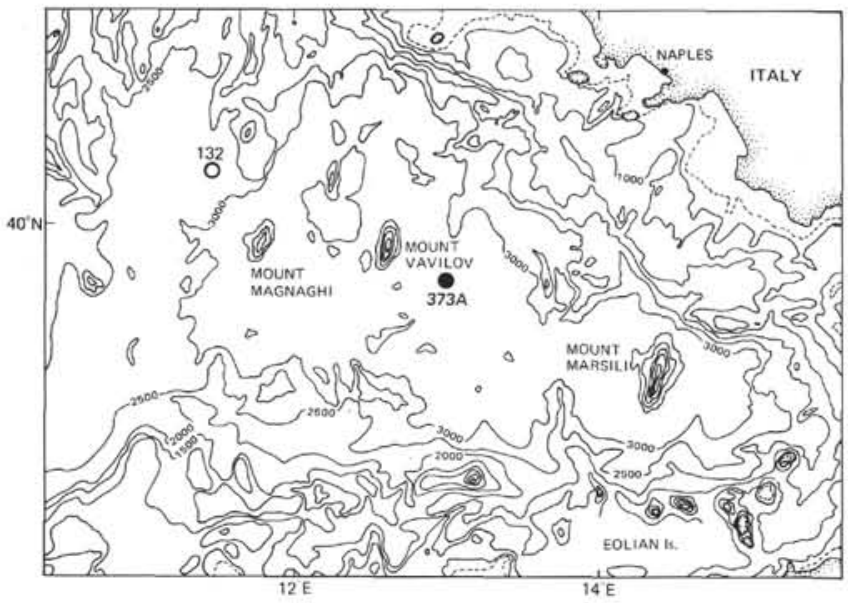

Figure 4. Location of Site 373 in the Tyrrhenian Sea.

pressure $\left(2.18 \pm 0.10 \mathrm{mcal} / \mathrm{cm} \mathrm{sec}{ }^{\circ} \mathrm{C}\right)$ made on the only core recovered from within this interval. The core was moderately disturbed by the coring process. Although bedding was still apparent, the extent to which the shipboard conductivity measurements represent the in situ thermal conductivity is certainly questionable. However, using the mean of the three conductivity values, a heat flow of $1.72 \times 10^{-6} \mathrm{cal} / \mathrm{cm}^{2}$ was calculated. This value is higher than the global heat-flow average of $1.45 \times 10^{-6} \mathrm{cal} / \mathrm{cm}^{2} \mathrm{sec}$ (Von Herzen and Lee, $1969)$, but somewhat lower than the mean $(2.83 \pm 1.07$ $\times 10^{-6} \mathrm{cal} / \mathrm{cm}^{2} \mathrm{sec}$ ) of 12 nearby Tyrrhenian Sea heatflow values which range from 0.72 to $4.14 \times 10^{-6} \mathrm{cal} /$ $\mathrm{cm}^{2} \mathrm{sec}$.

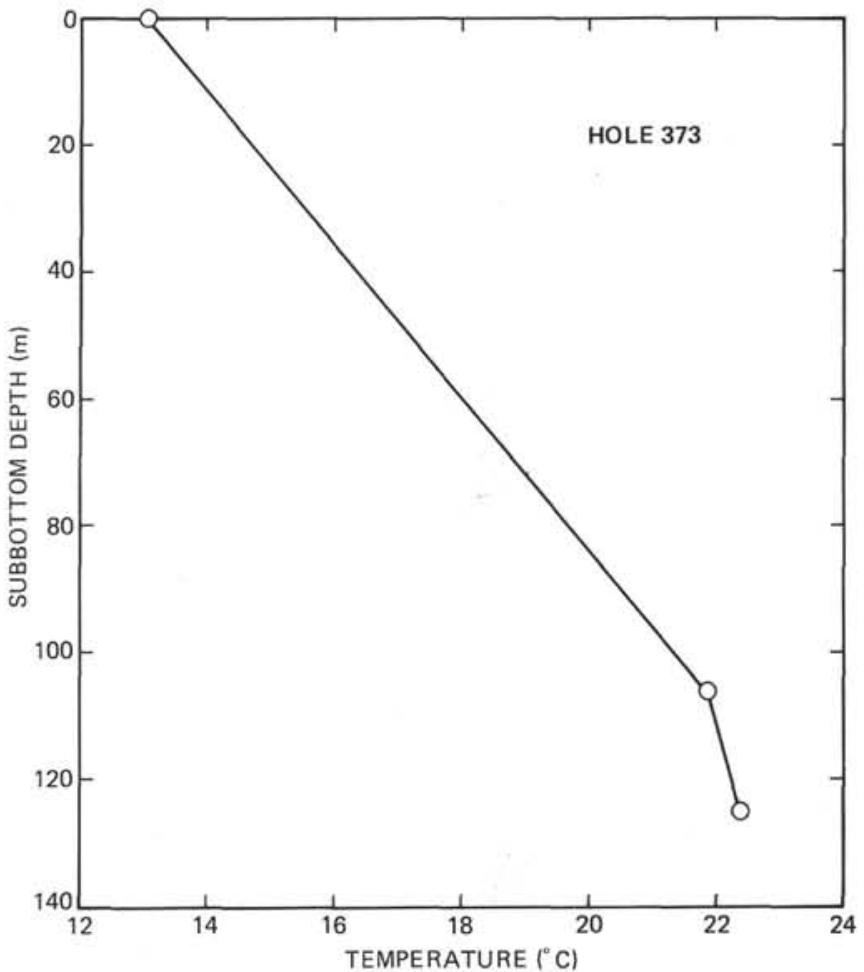

Figure 5. Plot of sediment temperature versus subbottom depth in Hole 373.

Possibly, the proximity of a basaltic seamount having a bulk thermal conductivity two to three times greater than the sediments in which the temperatures were measured caused a local reduction of the regional heat flow near the flanks of the seamount.

The determination of radiometric ages ranging from 3.5 to 7.5 million years for the basalt drilled at this site suggests that the seamount is no longer thermally active. Thus we believe the observed heat flow substantiates the existence of generally high regional heat flow in the Tyrrhenian Sea.

\section{Site 374}

Site 374 is in the central part of the Messinian Abyssal Plain in the Ionian Sea at a water depth of 4090 meters (Figure 6). The surrounding sea floor and subbottom topography are flat and undisturbed. Thus the measured heat flow at this location should be representative of the regional heat flow. Five downhole temperature measurements were made at this site to investigate the detailed structure of the geothermal gradient below 100 meters and to provide a reliable heat-flow value against which to compare conventional oceanographic heat-flow values in the Ionian Sea.

All five down-hole measurements were of excellent quality (Table 2) and were obtained with the same down-hole temperature recorder and thermistor combination, thus minimizing the possibility of calibration errors between different measuring systems. A bottom water temperature of $13.37^{\circ} \mathrm{C}$ was measured as the temperature probe was descended through the drill string just prior to its entry into the hole. 


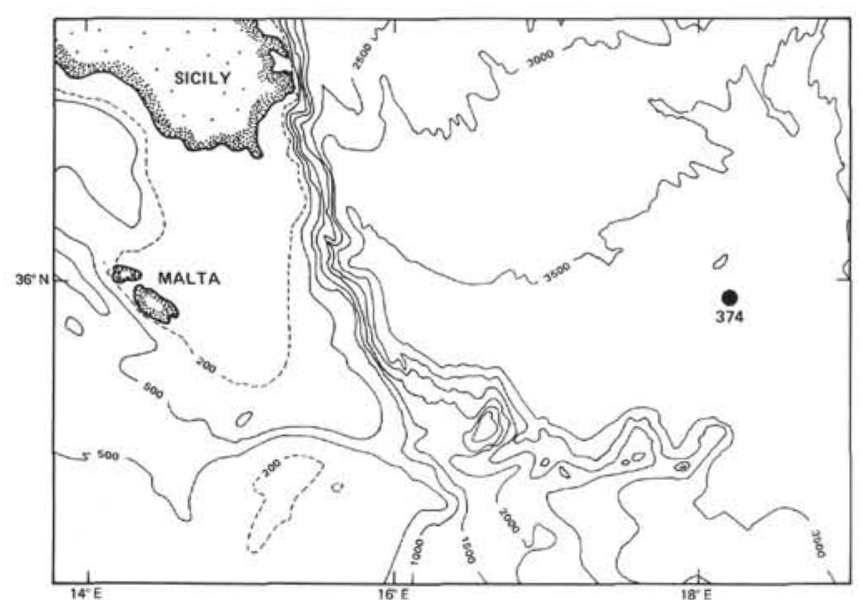

Figure 6. Location of Site 374 in the Ionian Sea.

Examination of Figure 7 shows that the geothermal gradient between the sea floor and the first down-hole temperature determination at 109.0 meters (32.5 $\left.\pm 2.9^{\circ} \mathrm{C} / \mathrm{km}\right)$ is substantially higher than the average geothermal gradient $\left(27.7 \pm 2.8^{\circ} \mathrm{C} / \mathrm{km}\right)$ determined on the basis of only the five down-hole measurements (Table 3). Although the temperature at 109.0 meters was well recorded, the bottom-hole assembly did not seem to penetrate to the same depth during the tem-

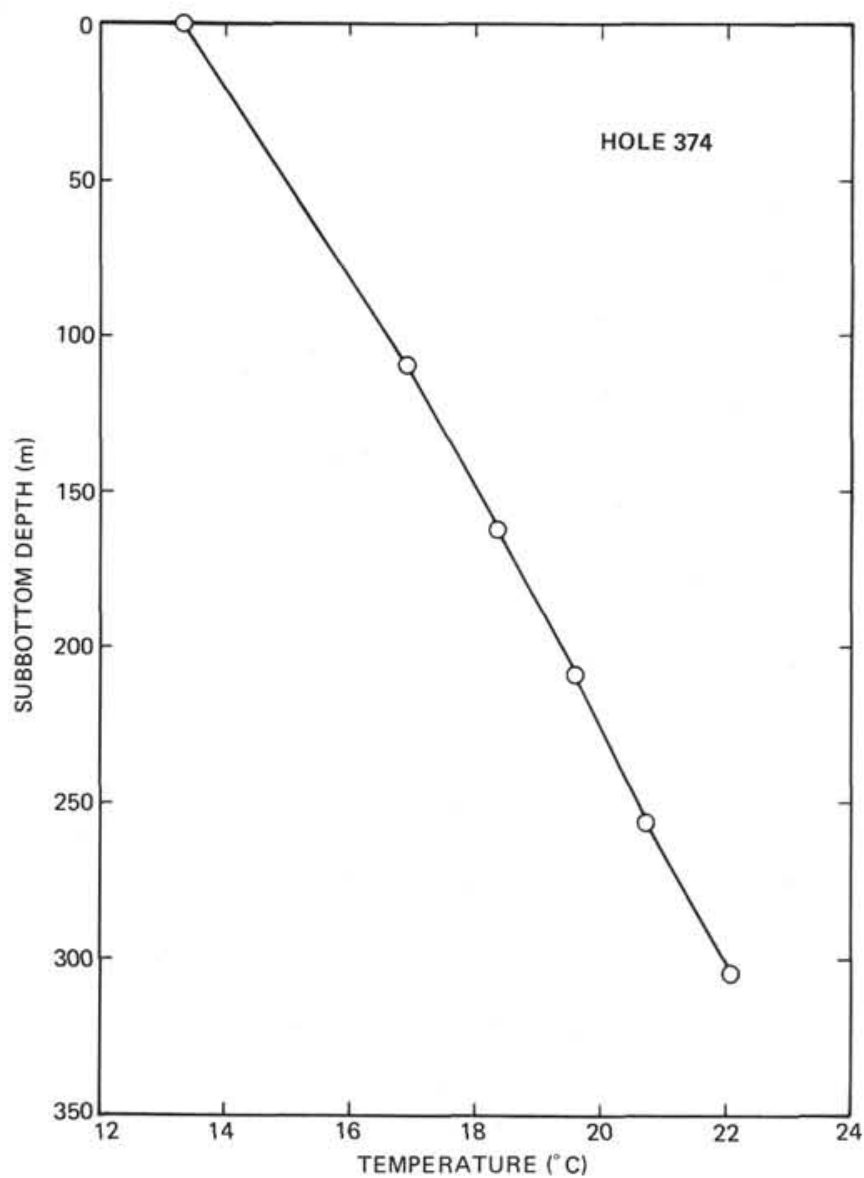

Figure 7. Plot of sediment temperature versus subbottom depth in Hole 374. perature measurement as it had while the hole was being drilled in preparation for the temperature measurement. Sandy turbidite layers were frequently encountered in the upper 150 meters at this site, and slumping of material into the hole prior to the temperature measurement probably caused the shallower penetration. The temperature measurement could then have been made in a mixture of seawater and cooler sediment slumped from further up in the hole, and the recorded temperature would be lower than the actual in situ sediment temperature at that depth. It is therefore somewhat surprising that the recorded temperature is in such excellent agreement with the gradient computed from the four deeper measurements.

The best estimate of the heat flow at Site 374 is 0.80 $\times 10^{-6} \mathrm{cal} / \mathrm{cm}^{2} \mathrm{sec}$, given by the product of the mean of the four interval geothermal gradients $\left(27.7 \pm 2.8^{\circ} \mathrm{C} /\right.$ $\mathrm{km})$ determined between 109.0 and 304.0 meters subbottom and the harmonic mean thermal conductivity of the sediment. The fact that temperature increases nearly linearly with depth (Figure 7) suggests that this area has not been subjected to large, long period fluctuations in bottom-water temperature within the last 2000 years. The heat-flow value is much lower than the global heat-flow average and is in good agreement with the average $\left(0.74 \pm 0.30 \times 10^{-6} \mathrm{cal} /\right.$ $\mathrm{cm}^{2} \mathrm{sec}$ ) of 33 conventional eastern Mediterranean heat-flow values (Erickson, 1970). The very low regional heat flow measured in the eastern Mediterranean supports other geophysical evidence indicating that this area has a fundamentally different origin and history than the western Mediterranean basins.

\section{Site 376}

Site 376 is in the eastern Mediterranean on the Florence Rise west of Cyprus (Figure 8). The Florence Rise rises about 600 meters above the adjacent Antalya and Levantine basins, to the north and south, . espectively, and is believed to have a tectonic origin as a large overthrust of probable Late Cretaceous age.

Five down-hole temperature measurements were made at Site 376 (Table 2). The presence of well-

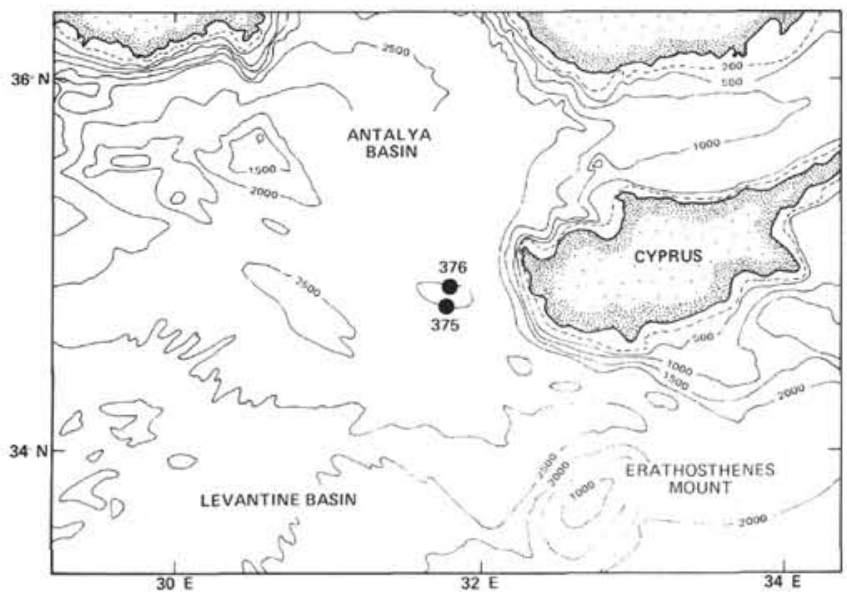

Figure 8. Location of Site 376 on the Florence Rise west of Cyprus. 
consolidated sediment near the sea floor at this site permitted us to make temperature measurements at shallower depths than is usually possible, thus we were able to examine variations in the thermal gradient in the uppermost 100 meters. The need for more detailed investigation of the thermal gradient in this interval was suggested by down-hole temperature data obtained at Site 374, where a significantly higher thermal gradient was detected between the sea floor and 109 meters subbottom than in the interval below 109 meters.

Down-hole temperature data obtained at this site vary widely in quality. For this reason, we include a brief discussion of the reliability of the measurements to assist in interpretation of the results.

The temperature data discussed above and listed in Table 2 are plotted against subbottom depth in Figure 9. The most striking feature of this plot is the reversal in the sign of the thermal gradient below 102.5 meters subbottom (see also Table 3 ). Using only bottom-water temperature and the uppermost three themperature values, an average thermal gradient of $32.6 \pm 14.9^{\circ} \mathrm{C}$ / $\mathrm{km}$ is calculated between the sea floor and 74 meters subbottom. Multiplying this value by the harmonic mean of the thermal conductivity values in the same interval, a heat flow of $0.94 \pm 0.35 \times 10^{-6} \mathrm{cal} / \mathrm{cm}^{2} \mathrm{sec}$ is obtained.

In order for this value to be geophysically significant, a satisfactory explanation for the gradient decrease and reversal below 74 meters must be found. A gradient reversal cannot be a steady-state phenomenon, but must be caused by either the drilling or the temperature measurement process itself. Some possible explanations are:

1) The recorder-thermistor combination used to obtain the lower two temperature values was malfunctioning and/or improperly calibrated. However, both instruments functioned normally before, during, and after these measurements.

2) The three temperatures recorded at $26.5,55.0$, and 74.0 meters were higher than the actual in situ sediment temperatures at those depths. This is highly unlikely as there is no plausible way to produce temperatures above the in situ sediment temperature. Frictional heat generated during drilling is carried away by the circulation of the drilling fluid, and frictional heat associated with penetration of the temperature probe into undrilled sediment is easily recoqnizable because of its characteristically short thermal decay time.

3) The lowermost two temperature measurements were made in slumped material and/or cool drilling fluid, rather than in thermally undisturbed sediment ahead of the drill bit. The fact that cooler temperatures were recorded at 131 meters than at 102.5 meters would suggest that slumping was more significant for the deeper measurement. Indeed, the shape of the temperature-time plot of the data recorded at 131 meters (Figure lp) shows an unusual shape characterized by a short period of cooling followed by a long period of warming. This is similar to what one would

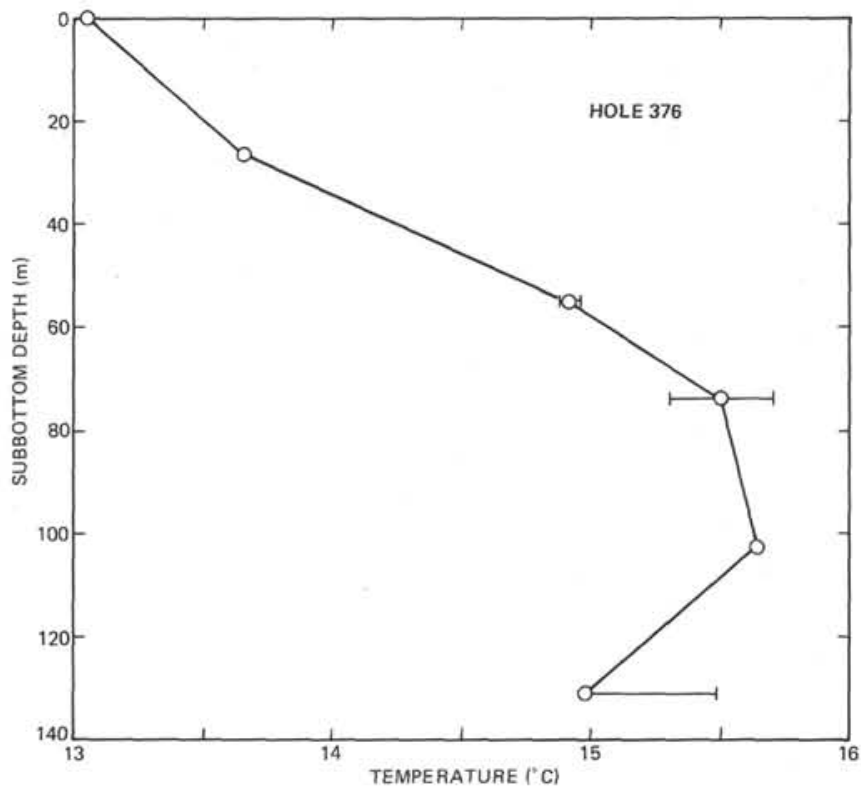

Figure 9. Plot of sediment temperature versus subbottom depth in Hole 376.

expect if the temperature probe were immersed in a plug of cool, unconsolidated sedimentary debris which was slowly approaching thermal equilibrium with the warmer sediment surrounding the borehole. Although this is a reasonable explanation for the lowest temperature measurement, temperatures at 102.5 meters show no evidence of warming during the measurement period (Figure 1o), and indeed the measurement has all the appearances of being a highly reliable in situ sediment temperature determination.

4) Oceanographic or geological effects: The nonlinearity of the temperature-depth profile could also have been caused by extreme variations in bottom water temperature. The general form of the profile observed at Site 376 would require that a period of very cold bottom-water temperatures was followed by a period of very warm temperatures which gave way to a strong and continuing cooling trend manifested by the positive gradient observed in the uppermost sediments. The down-hole temperature data indicates that the effects of the latest cooling trend had not yet penetrated below 74 meters. Consequently, by assuming that the bottom water temperature decreased suddenly, we could set an upper limit of about 100 years during which cooling had been in progress. There are, however, no other data to support such strong cooling over this period, and we consider it unlikely to have occurred.

Other geologically interesting, but unlikely, possibilities include the thermal effects of the emplacement of a coherent slab of material containing a normal geothermal gradient over cooler material which had once been at the sea floor. The cooler material then slowly warmed to thermal equilibrium by absorbing heat both from below and from the still warmer layer above. Such emplacement could occur either by slumping from a higher level or by low angle thrusting. The 


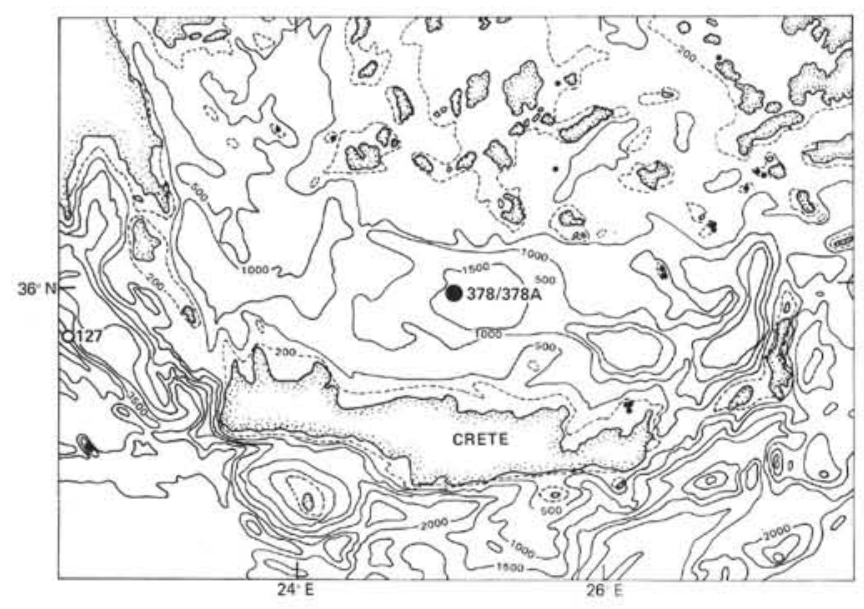

Figure 10. Location of Site 378 in the southern Aegean Sea.

temperature data suggest that if such a process had occurred it must have involved a layer at least 130 meters thick. No evidence for slumped or otherwise superposed sediment layers of this thickness were noted at either Sites 375 or 376.

Recent experiences in logging temperatures in holes drilled into ocean basalts suggest that the drilling process can open new pathways for active fluid flow between the sea floor and deeper permeable layers. The loss of pump pressure while drilling the evaporitic sediments between 205 and 207 meters subbottom at this site has been attributed to drilling into some sort of cavern or highly permeable horizon. The sediments in the interval 102.5 to 131.0 meters subbottom are nannofossil marls rather than evaporites, and no loss of circulation was noted while drilling through that interval. Nonetheless, initiation of slow movement of cool water down a newly drilled hole, already observed in ocean crust drilling during Legs 37 (Hyndman et al., 1976) and 46 (Erickson and Hyndman, in press) could cause down-hole temperatures similar to those observed at this site.

\section{Site 378}

Site 378 is in a sediment pond in the southern Aegean Sea north of Crete in 1835 meters of water (Figure 10). Two down-hole temperature measurements were made at Hole 378 and a third at Hole $378 \mathrm{~A}$, offset only 10 or 20 meters from Hole 378 . Calm seas and the absence of unstable, sandy, or coarse sediment resulted in all three measurements being of high reliability.

The equilibrium sediment temperatures calculated from each of the temperature-versus-time plots are listed in Table 2 and plotted versus subbottom depth in Figure 11. The down-hole temperature measurement made at 122 meters subbottom was unusual in that it showed no apparent frictional heating, and that it slowly reached a temperature maximum about $4 \mathrm{~min}$ utes after penetration and then slowly began to cool (Figure 1g). We believe the maximum temperature attained $\left(23.07^{\circ} \mathrm{C}\right)$ is the best estimate of the in situ

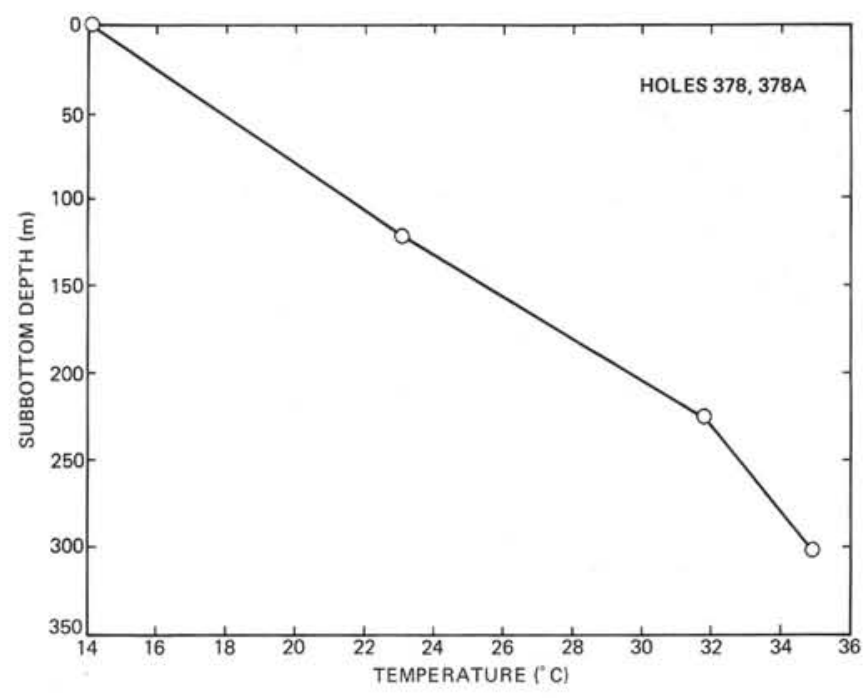

Figure 11. Plot of sediment temperature versus subbottom depth in Holes 378 and $378 \mathrm{~A}$.

sediment temperature. It is possible that the probe only penetrated a short distance into the undrilled, thermally undisturbed sediment, or that in penetrating the sediment it opened a channel permitting cool water to penetrate downwards to the tip. The smoothness of the curve following penetration indicates the absence of any movement of the probe relative to the sediment during the measurement interval. The two additional temperature measurements at 226.5 meters and 302.5 meters subbottom are both reliable. A new thermistor probe was used at 226.5 meters, and a correction of $+0.08^{\circ} \mathrm{C}$ has been added to bring the water temperature $\left(14.51^{\circ} \mathrm{C}\right)$, measured in the drill pipe, into better agreement with water temperatures recorded during the other two measurements. The deeper measurement showed that an unusually large amount of frictional heating occurred upon penetration and that it was still cooling towards thermal equilibrium when the measurement ended.

The three down-hole temperature measurements plus the bottom-water temperature measurement define three intervals over which the geothermal gradient can be calculated. By multiplying each of the gradients by the harmonic mean thermal conductivity of the sediment in that interval, three interval heat-flow values were calculated (Table 3 ). Under steady-state conditions, the heat flow through each interval should be constant. As shown in Table 3, the heat flows calculated through the upper two intervals are approximately equal, while the flux through the deepest interval is much lower, despite a significant increase in thermal conductivity. A geologic situation which could temporarily result in the creation of a higher nearsurface geothermal gradient is rapid erosion and/or recent or continuing long-term cooling of the Aegean bottom water. If the increased gradient above about 226.5 meters is a result of erosion the layer must have been about 200 meters thick and have been removed approximately 1000 years ago. The site, however, was drilled on the floor of a sediment pond and the recent 
removal of 200 meters of sediment is very unlikely. Furthermore, there is no evidence for missing sediments of Pleistocene age here. In order to explain the higher near-surface gradient by cooling bottom water temperatures, the cooling must have been continuing during the last 1000 years, and amounted to about $8^{\circ} \mathrm{C}$. There is no evidence of or reasonable explanatiion for such a change.

Instead, it is more likely that the deepest down-hole temperature measurement was made in a mixture of slumped sediment and drilling mud at the bottom of the hole. Alternatively, the temperature measurement at 302.5 meters was made in a different hole than those made at 122.0 and 226.5 meters. The best heat-flow value for this site is $2.12 \pm 0.11 \times 10^{-6} \mathrm{cal} / \mathrm{cm}^{2} \mathrm{sec}$, the average of the heat-flow values measured in the upper two intervals.

This value is in excellent agreement with the mean $\left(1.98 \pm 0.55 \times 10^{-6} \mathrm{cal} / \mathrm{cm}^{2} \mathrm{sec}\right)$ of 9 conventional heat-flow measurements in the central and northern Aegean, but is substantially higher than the values in the southern Aegean ( 1.01 to $1.64 \times 10^{-6} \mathrm{cal} / \mathrm{cm}^{2} \mathrm{sec}$ ) close to Site 378, all four of which are characterized by thermal gradients which vary systematically with depth (Jongsma, 1974).

The substantially higher heat-flow calculated from temperatures measured below the level to which seasonal temperature fluctuations can penetrate suggest that conventional heat-flow measurements in the southern Aegean were lowered by the seasonal increase in bottom-water temperature, and that the entire Aegean Sea is a region of uniformly high heat flow (Table 4).

TABLE 4

Summary of Heat-Flow Values Calculated From Down-Hole Temperature Measurements and Thermal Conductivity Data Obtained During DSDP Leg 42A

\begin{tabular}{|c|c|c|c|c|c|}
\hline \multirow[b]{2}{*}{ Site } & \multicolumn{2}{|c|}{ Position } & \multirow[b]{2}{*}{ Physiographic Region } & \multirow{2}{*}{$\begin{array}{l}\text { Water Depth } \\
\text { (corr, m) }\end{array}$} & \multirow{2}{*}{$\begin{array}{l}\text { Heat Flow } \\
\left(\mu \mathrm{cal} / \mathrm{cm}^{2} \mathrm{sec}\right)\end{array}$} \\
\hline & Latitude & Longitude & & & \\
\hline 372 & $40^{\circ} 01.90^{\prime} \mathrm{N}$ & $04^{\circ} 47.79^{\prime} \mathrm{E}$ & East Menorca Rise & 2699 & $2.46 \pm 0.16$ \\
\hline 373 & $39^{\circ} 43.68^{\prime} \mathrm{N}$ & $12 \div 59.56^{\prime} \mathrm{E}$ & Tyrrhenian Sea & 3517 & $1.72 \pm 0.25$ \\
\hline 374 & $35^{\circ} 50.87^{\prime} \mathrm{N}$ & $18^{\circ} 11.78^{\prime} \mathrm{E}$ & Messina Abyssal Plain & 4078 & $0.80 \pm 0.10$ \\
\hline 376 & $34^{\circ} 52.32^{\prime} \mathrm{N}$ & $31^{\circ} 48.45^{\prime} \mathrm{E}$ & $\begin{array}{l}\text { Florence Rise south- } \\
\text { west of Cyprus }\end{array}$ & 2101 & $0.94 \pm 0.35$ \\
\hline 378 & $35^{\circ} 56.67^{\prime} \mathrm{N}$ & $25^{\circ} 06.97^{\prime} \mathrm{E}$ & Southern Aegean Sea & 1835 & $2.12 \pm 0.25$ \\
\hline
\end{tabular}

\section{DISCUSSION}

\section{Environmental Effects}

Local and regional geological, oceanographic, and tectonic factors can cause the measured, near-surface heat flow to be either greater or smaller than the regional, geophysically relevant heat flow. In order to interpret geophysical aspects from the heat-flow values, we must estimate the magnitude of the environmental effects and use them to correct the measured heat flow. These corrections require knowledge of the rate and duration of sedimentation, the long- and short-term history of bottom-water temperature variations, and the topography of the sea floor and the subbottom layers.

The main purpose of this discussion is to consider the existence of geophysically significant regional dif- ferences in the heat flow through the floors of the western Mediterranean, eastern Mediterranean, and Aegean basins and to demonstrate that the regional environmental corrections are small enough that the application of these corrections does not significantly alter the deductions derived from the measured heatflow values.

The generally good agreement between the conventional oceanographic and deep hole heat-flow measurements suggests that seasonal bottom-water temperature variations have not significantly influenced the temperature distribution in the uppermost 10 meters of sediment, except in the southern Aegean Sea. Furthermore, persistence of nearly linear temperature-depth relationships to subbottom depths of 155 meters, 304 meters, and 226 meters in the western Mediterranean, Ionian, and Aegean seas, respectively, suggests that bottom-water temperature have not undergone large amplitude, long-term changes during the last few thousand years.

Thermal refraction is caused by the preferential flow of heat through high thermal conductivity (rock or salt) materials and around low thermal conductivity (sediment) deposits. Thermal refraction can significantly affect the measured heat flow in areas of shallowly buried, rough topography formed of materials with strongly contrasting thermal conductivity properties (Selig and Wallick, 1966; Von Herzen and Uyeda, 1963; Sclater et al., 1970a, b; Lee and Henyey, 1974). Thermal refraction alters the local distribution of heat flow, rather than the average regional heat flow. The widespread presence of highly conductive evaporite layers and associated salt domes and ridges (Mauffret et al., 1973) beneath the western and eastern Mediterranean seas suggests that thermal refraction may locally affect the measured heat-flow values, especially where there is substantial subbottom relief on the evaporitic layer and/or the structures are thinly buried. However, since the locations of the measurements were generally determined independently of the subbottom structure, the average of the heat-flow values measured above, along side of, and far from highly conductive subbottom structures should yield a value close to the average regional heat flow.

The ability of long-term sedimentation to lower the measured heat-flow value is widely known (Von Herzen and Uyeda, 1963; Jaeger, 1965; and Langseth, 1965). The generally thick and highly variable accumulations of sediment in the various Mediterranean basins suggest that sedimentation may have systematically decreased the measured heat-flow value by significant and variable amounts. In order to estimate the effects of sedimentation in the various regions, the sedimentary history (rate and duration of sedimentation) for each area must be known or estimated. These factors are still poorly known, and thus the sedimentation corrections derived from them are intended only to set limits on the effects, and thus on estimates of the regional heat flow through the various regions.

Sedimentation rates have been estimated at most of the Deep Sea Drilling Project sites drilled in the Mediterranean during Legs 13 and 42A. Sedimentation 
rates as high as $31.3 \mathrm{~cm} / 1000 \mathrm{yr}$ have been calculated for the Pleistocene deposits. Pliocene and, where available, Miocene sedimentation rates are generally less than about $10.0 \mathrm{~cm} / 1000 \mathrm{yr}$ (Cita, Ryan, and Kidd, this volume) at drill sites throughout the Mediterranean and Aegean basins. Averages of Pliocene-Pleistocene sedimentation rates in the eastern and western Mediterranean are approximately equal (6.69 and 5.58 $\mathrm{cm} / 1000 \mathrm{yr}$, respectively) and bracket the single sedimentation rate calculated for the southern Aegean Sea $(6.0 \mathrm{~cm} / 1000 \mathrm{yr})$. A major uncertainty is whether or not we can reasonably assume the same sedimentation rate for times earlier than the Pliocene-Pleistocene and late Miocene, and just how far back in time one should extrapolate (i.e., how old is the basin?). Furthermore, many of the drill sites were situated in areas chosen for their low sedimentation rates in order to maximize the possibility of drilling into older sediments, and thus may not be representative of the basin as a whole.

Acceptance of an average sedimentation rate of 6 $\mathrm{cm} / 1000 \mathrm{yr}$ (expanded to $10 \mathrm{~cm} / 1000 \mathrm{yr}$ to account for compaction) since the beginning of the Miocene (20 m.y.B.P.) and the early Tertiary (60 m.y.B.P.), ages frequently cited for the creation of the western (Auzende and Olivet, 1974; Mauffret et al., 1973) and eastern Mediterranean seas, yields corrected heat-flow values for the western and eastern Mediterranean of 2.83 and $1.07 \times 10^{-6} \mathrm{cal} / \mathrm{cm}^{2} \mathrm{sec}$, respectively. Use of these figures almost surely underestimates the effect of sedimentation in the western Mediterranean where the observed sediment thickness is greater than that which could be deposited using the above parameters.

Another method to estimate the sedimentary history is to use geophysical data to determine the average thickness and age of the sedimentary layers in the various basins to calculate an average sedimentation rate and duration for each region. Unfortunately this method also requires the application of many questionable assumptions. Estimates of the ages of the various reflectors vary between investigators and detection and/or identification of the base of the sedimentary sequence is often difficult.

Table 5 was prepared using what appear to be average values for the ages and thicknesses of the sediment layers in the various Mediterranean basins. Generally good agreement exists among investigators for the thickness and age of the uppermost sediment layer, which rests on strongly reflecting upper Miocene evaporitic and salt layers throughout most of the western and eastern Mediterranean. There is much less agreement on the maximum age and thickness of the sediment(?) layers beneath the salt layer. The values chosen for Table 5 represent a general average of the estimates presently in the literature.

Corrected heat-flow averages were calculated for both the well-known post-Miocene sedimentation, and for the less well-known pre-Pliocene sedimentation history. In both cases, the heat flux through the western Mediterranean and Tyrrhenian basins is at least three times as great as the heat flow through the floor of the eastern Mediterranean Sea. This difference is princi- pally in the measured heat fluxes in the two regions rather than a result of the estimated effects of sedimentation. The small effect of sedimentation on heat flow in the eastern Mediterranean is further suggested by the similarity of terrestrial heat-flow values, measured in holes on Cyprus (Morgan, in press), to marine heatflow values, measured in the regions immediately surrounding the eastern Mediterranean. Because the sediment is thinner and measured heat flow is higher in the Tyrrhenian Basin than in the other western Mediterranean basins, the corrected heat-flow values are nearly equal through both regions. This is somewhat surprising in view of the evidence for active volcanism in and around the Tyrrhenian Sea as contrasted with the general absence of volcanism in the Mediterranean basins further west. The existence of heat flow much higher than $5.70 \times 10^{-6} \mathrm{cal} / \mathrm{cm}^{2} \mathrm{sec}$ (Table 4) is unlikely because an unreasonably high temperature would have to exist at the base of the 6 or $7 \mathrm{~km}$ thickness of sediment present in the northwestern Mediterranean (Mauffret et al., 1973). If we assume an average thermal conductivity of $5 \times 10^{-3} \mathrm{cal} / \mathrm{cm} \mathrm{sec}^{\circ} \mathrm{C}$, typical of consolidated terrigenous sedimentary rocks (Clark, 1966, Table 21-1), temperatures at the base of $7 \mathrm{~km}$ of sediment should be well over $600^{\circ} \mathrm{C}$. That such is not the case is indicated by the presence of well-defined, low amplitude magnetic anomalies throughout the Balearic Basin (Bayer et al., 1973). The presence of magnetic anomalies, presumed to originate from beneath rather than from within the sediments, requires that the basement temperatures are less than the Curie point of the common magnetic minerals $\left(\cong 550^{\circ} \mathrm{C}\right.$ ), and must be less than the blocking temperature which, for basalt more than a few million years old, is in the range of $300^{\circ}$ to $500^{\circ} \mathrm{C}$ (Irving, 1970). Again assuming an average thermal conductivity of 5 $\times 10^{-3} \mathrm{cal} / \mathrm{cm} \mathrm{sec}{ }^{\circ} \mathrm{C}$, and that the temperature at the base of $7 \mathrm{~km}$ of sediment is $450^{\circ} \mathrm{C}$ hotter than the sea floor, a maximum heat flow of $3.21 \times 10^{-6} \mathrm{cal} / \mathrm{cm}^{2} \mathrm{sec}$ can be computed. This value is nearly equal to $3.13 \times$ $10^{-6} \mathrm{cal} / \mathrm{cm}^{2} \mathrm{sec}$, the measured heat-flow value corrected for the effects of Pliocene-Pleistocene sedimentation (Table 5).

The variability of the heat-flow values in the western Mediterranean Basin is surprising in view of the thick, generally horizontal sediments and the absence of volcanic or intrusive activity over much of the region. Much of the variability in the heat flow is probably a result of thermal refraction caused by salt domes and salt ridges (Selig and Wallick, 1966), made of dolomite, anhydrite, and rock-salt having thermal conductivities four to five times greater than those or near-surface unconsolidated sediments (Clark, 1966, Table 12-2). Diapiric structures are close to or even protrude above the sea floor at many places in the Balearic Basin (Stanley et al., 1974) and the northwestern Mediterranean (Mauffret et al., 1973). Heat-flow values, measured in the Atlantic on the crests of diapiric structures on the continental slope west of Angola, were systematically two or three times larger than those measured between the diapirs (Von Herzen 
TABLE 5

Summary of Sedimentation Corrections for Various Regions of the Mediterranean Sea, Giving the Assumed Sediment Thicknesses and Duration of Sedimentation Necessary for Calculation of the Sedimentation Effect

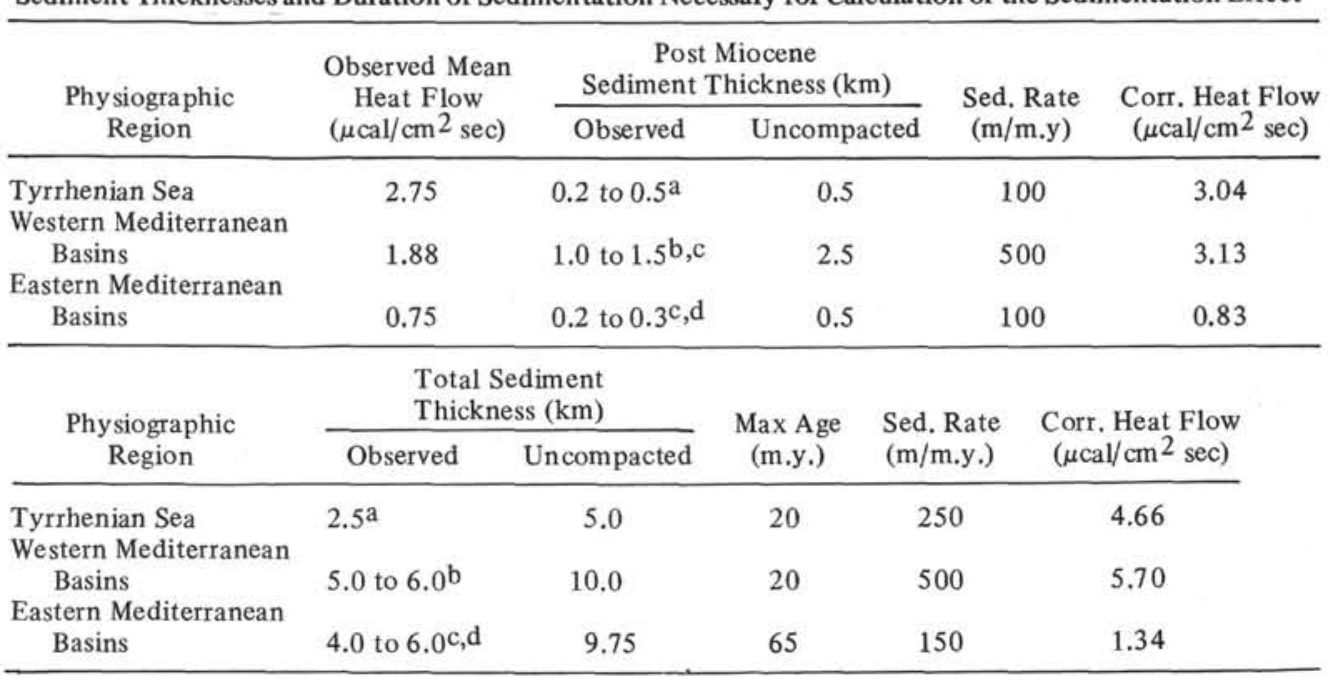

Note: Great controversy remains over the age and sedimentary history of the Mediterranean, and the above table is included only to provide a range of probable corrections, rather than any precise value of the sedimentation effect or the corrected heat flow.

${ }^{\mathrm{a}}$ Finetti et al. (1970).

${ }^{b}$ Mauffret et al. (1973).

Finetti and Morelli (1972).

$\mathrm{d}_{\text {Sancho et al. (1973). }}$.

et al., 1972). In addition to the effects of thermal refraction, movement of the salt has, in some regions, produced sea floor relief of as much as several meters, which in itself may contribute to variability in the nearsurface thermal gradient as well as modify the sediment dispersal pattern (Stanley et al., 1974).

\section{Relation of Regional Heat-flow Differences and Diapiric Phenomena}

Lateral variations in the size, shape, and abundance of halokinetic structures were noted by Stanley et al. (1974) and Mauffret et al. (1973). Mauffret et al. (1973), after considerinq the effects of variations in salt thickness, the thickness and the nature of the sedimentary overburden, and tectonic influence, concluded that there is no simple explanation for the morphological variety of the salt structures in the western Mediterranean. They did note, however, that vertical faulting seems to play an important role. Perhaps the much greater abundance of diapiric structures in the western Mediterranean compared with most of the eastern Mediterranean where the salt and evaporitic layers, though present, are generally flat lying, was caused by temperature differences at depth. The higher heat flow and greater thickness of Pliocene-Pleistocene sediments in the western Mediterranean would suggest greater temperatures beneath the western Mediterranean sea floor. Gussow (1968) stated that "increased temperature greatly reduces the ultimate strength and eliminates work hardening. When salt is heated above $400^{\circ} \mathrm{F}\left(205^{\circ} \mathrm{C}\right)$, it becomes soft and plastic and flows indefinitely with a pressure gradient of about 33-100 $\mathrm{kg} / \mathrm{cm}^{2}$ (460 to $1400 \mathrm{psi}$ )."
Measured thermal gradients in DSDP holes in the western Provençal (Site 372) and Ionian (Site 374) basins are in the ranges $76^{\circ} \mathrm{C} / \mathrm{km}$ and $28^{\circ} \mathrm{C} / \mathrm{km}$, respectively. The western Mediterranean salt layer, up to $1.2 \mathrm{~km}$ thick, is overlain by 1 to $1.5 \mathrm{~km}$ of PliocenePleistocene sediments and 600 meters of upper Miocene evaporites. Even allowing for the high thermal conductivity of the evaporites and salt, temperatures near the base of the salt layer $3 \mathrm{~km}$ beneath the sea floor should be close to $200^{\circ} \mathrm{C}$.

Salt beneath the eastern Mediterranean, with its lower thermal gradient and much thinner cover of Pliocene-Pleistocene sediments, will be at a lower temperature. Pliocene/Pleistocene sediments, only 300 meters thick in much of the Ionian Sea, overly a $2-\mathrm{km}$ evaporitic layer (Finetti and Morelli, 1972). Temperatures at the base of the thick, but highly conductive salt layer, would be less than $50^{\circ} \mathrm{C}$. The low temperatures may well inhibit the development of diapiric structures except in areas where tectonic effects are important (Ross and Uchupi, in press).

\section{SUMMARY AND CONCLUSIONS}

We conclude that the difference between the mean regional heat flow through the floors of the eastern Mediterranean and the western Mediterranean seas is geophysically significant, and is primarily caused by the presence of hotter mantle material at shallower depths beneath the western Mediterranean and Aegean Sea than beneath the eastern Mediterranean.

That heat flow is higher and more variable in the Tyrrhenian Sea than in the other western Mediterra- 
nean basins, in conjunction with the distribution of seismic and volcanic activity, indicates that the Tyrrhenian is currently underlain by hot, mobile mantle material and is tectonically active, both in its central and peripheral regions. This conclusion supports tectonic models in which the Tyrrhenian Sea is a back-arc basin produced as a consequence of the subduction of the lithosphere beneath the Ionian Sea.

The remaining western Mediterranean basins are also characterized by high heat flow, although it is lower and less variable than that measured through the floor of the Tyrrhenian Sea. Because sediments are thicker in the western Mediterranean basins than in the Tyrrhenian Sea, the sea-floor topography is flatter and layers having higher thermal conductivity than the overlying sediments are (with the notable exception of salt diapirs) either absent or more deeply buried. Thus their ability to produce heat-flow variability through thermal refraction is reduced or removed. It is surprising and probably significant that high heat-flow values are distributed rather uniformly throughout the western Mediterranean, even as far west as the Alboran Basin. Whatever process produces the high heat flow is thus effective beneath the entire western Mediterranean. Creation of the western Mediterranean by rifting (Bayer et al., 1973), whether from a land-locked midocean ridge segment, by induced flow behind an island arc (Andrews and Sleep, 1974), or in response to the translation and rotation of microcontinents (Alvarez et al., 1974) is unlikely in view of the regionally high heat flow and occurrence of widespread, generally flat-lying, undisturbed sediments, including the distinctive upper Miocene salt layer.

The uniformly low heat flow throughout the entire eastern Mediterranean is not consistent with the explanation that the low heat flow is caused by a depression of the isotherms as the floor of the eastern Mediterranean is subducted beneath the Hellenic arc (Erickson, 1970). Recent and continuing compression, thickening, and consequent uplift of the Mediterranean ridge, as evidenced by the presence of elevated turbidite layers (Hsü and Ryan, 1973), would produce low heat flow, and in fact may be responsible for some of the exceptionally low heat-flow values observed on the Mediterranean ridge. However, this explanation cannot explain the regionally low heat flow. Furthermore, the heatflow values on the ridge are not systematically lower than heat-flow values in adjacent undeformed regions. A more appealing, but speculative, interpretation is formulated largely on the basis of evidence presented by Jordan (1975) for the existence of temperature and compositional differences beneath oceans and continents to depths exceeding $400 \mathrm{~km}$. If the temperature and radiogenic heat production in the asthenosphere beneath the continents is lower than that beneath oceanic lithosphere, then a possible effect of plate movement-in particular, of continent to continent collisions-might be the displacement of oceanic lithosphere onto or over continental asthenosphere (or visa versa). We suggest that this has, or is, occurring beneath the eastern Mediterranean as a result of the northward movement of cool, poorly radiogenic asthenosphere from beneath Africa, which causes the displacement of the hotter originally oceanic eastern Mediterranean asthenosphere northwards and downwards beneath the Aegean Sea, Turkey, and southeastern Europe.

Occurrence of high heat flow in the southern Aegean, where heat-flow measurements using oceanographic techniques had proven unreliable due to the effect of bottom-water temperature variations (Jongsma, 1974), is consistent with, but does not require, the previous concept. Previous oceanographic heat-flow measurements showed higher heat flow in the northern Aegean than in the south, thus indicating spreading in the northern Aegean as suggested previously by Vogt and Higgs (1969) on the basis of aeromagnetic data. The conclusion that the area of high heat flow covers the entire Aegean Sea removes some support for spreading in the northern Aegean.

\section{ACKNOWLEDGMENTS}

We wish to express our sincere appreciation for the cooperation of all of the personnel aboard the D/V Glomar Challenger. In particular, the downhole temperature data could not have been obtained without the help provided by Mr. Robert Byrnes, DSDP electronics technician, or without the assistance, advice, and expertise provided by the drilling crew. We further wish to thank the Co-Chief Scientists, Ken Hsü and Lucien Montadert, for their assistance, advice, and for allocating the ship's time required to carry out a successful heat-flow program.

\section{REFERENCES}

Alvarez, W., Cocozza, T., and Wezel, F. C., 1974. Fragmentation of the Alpine orogenic belt by microplate dispersal: Nature, v. 248, p. 309-314.

Andrews, D. and Sleep, N., 1974. Numerical modelling of tectonic flow behind island arcs: Geophys. J. Roy. Astron. Soc., v. 38, p. 237-251.

Auzende, J. M. and Olivet, J. L., 1974. Structure of the Western Mediterranean basin. In Burk, C. A. and Drake, C. L., (Eds.), The geology of continental margins: New York (Springer-Verlag), p. 723-731.

Bayer, R., Le Mouel, J. L., and Le Pichon, X., 1973. Magnetic anomaly pattern in the Western Mediterranean: Earth Planet. Sci. Lett., v. 19, p. 168-176.

Birch, F. S. and Halunen, A. J., Jr., 1966. Heat-flow measurements in the Atlantic Ocean, Indian Ocean, Mediterranean Sea, and Red Sea: J. Geophys. Res., v. 71, p. 538-586.

Bullard, E. C. and Day, A., 1961. The flow of heat through the floor of the Atlantic Ocean: Geophys. J., v. 4, p. 282292.

Clark, S. P., 1966. Thermal conductivity: In Clark, S. P., (Ed.), Handbook of physical constants, Geol. Soc. America Mem., 97: New York (Geol. Soc. America), p. 459482.

Erickson, A. J., 1970. The measurement and interpretation of heat flow in the Mediterranean and Black Seas: Unpublished Ph.D. thesis, Massachusetts Institute of Technology, Cambridge, Massachusetts.

Erickson, A. J., 1973. Initial report on downhole temperature and shipboard thermal conductivity measurements, Leg 19: In Creager, J. S., Scholl, D. W., et al., Initial Reports 
of the Deep Sea Drilling Project, Volume 19: Washington (U.S. Government Printing Office), p.643-656.

Erickson, A. J. and Hyndman, R. D., in press. Geothermal measurements, DSDP Leg 46. In Initial Reports of the Deep Sea Drilling Project, Volume 46: Washington (U.S. Government Printing Office).

Erickson, A. J., Von Herzen, R. P., Sclater, J. G., Girdler, R. W., Marshall, B. V., and Hyndman, R., 1975. Geothermal measurements in deep-sea drill holes: J. Geophys. Res., v. 80 , p. $2515-2528$.

Finetti, I. and Morelli, C., 1972. Wide scale digital seismic exploration of the Mediterranean Sea: Boll. Geof. Teorica ed Applicata, v. 14, p. 291-342.

Finetti, I., Morelli, C. and Zarudzki, E., 1970. Reflection seismic study of the Tyrrhenian Sea: Boll. Geof. Teorica ed Applicata, v. 12, p. 311-346.

Gussow, W. C., 1968. Salt diapirism: Importance of temperature, and energy sources of emplacement: In Braunstein, J. and O'Brien, G. D., (Eds.), Diapirism and diapirs, American Assoc. Petrol. Geol. Memoir No. 8: Tulsa, Oklahoma (Am. Assoc. Petrol. Geol.).

Haenel, R., 1972. Heat-flow measurements in the Ionian Sea with a new heat flow probe: Meteor Forsch.-Ergenb., Reihe C., v. 11, p. 105-108.

Hsü, K. J. and Ryan, W. B. F., 1973. Summary of the evidence for extensional and compressional tectonics in the Mediterranean, In Ryan, W. B. F., Hsü, K. J., et al., Initial Reports of the Deep Sea Drilling Project, Volume 13: Washington (U.S. Government Printing Office), p. 1011-1019.

Hyndman, R. D., Von Herzen, R. P., Erickson, A. J., and Jolivet, J., 1976. Heat-flow measurements in deep crustal holes on the Mid-Atlantic ridge: J. Geophys. Res., v. 80, p. 4042-4052.

Irving, E., 1970. The Mid-Atlantic ridge at $45^{\circ} \mathrm{N}$. XIV. Oxidation and magnetic properties of basalt; review and discussion: Canadian, J. Earth Sci., v. 7, p. 1528-1538.

Jaeger, J. C., 1965. Applied theory of heat conduction: In Lee, W. H. K. (Ed.), Terrestrial heat flow: American Geophys. Union Mono. No. 8, Washington (American Geophys. Union), p. 7-23.

Jongsma, D., 1974. Heat flow in the Aegean Sea: Geophys. J. Roy. Astron. Soc., v. 37, p. 337-346.

Jordan, T. H., 1975. The continental tectosphere: Rev. Geophys. Space Physics, v. 13, p. 1-12.

Langseth, M. G., 1965. Techniques of measuring heat flow through the ocean floor: In Lee, W. H. K. (Ed.), Terrestrial heat flow; American Geophys. Union Monogr. No. 8, Washington (American Geophys. Union), p. 58-77.

Lavenia, A., 1967. Heat-flow measurements through bottom sediments in the southern Adriatic Sea: Boll. Geof. Teorica ed Applicata, v. 9, p. 323-332.

Lee, T. C. and Henyey, T. L., 1974. Heat-flow refraction across dissimilar media: Geophys. J. Roy. Astron. Soc., v. 39 , p. 319-333.

Lister, C. L., 1963. Geothermal gradient measurement using a deep-sea corer: Geophys. J. Roy. Astron. Soc., v. 7, p. 571-583.

Mauffret, A., Fail, M. P., Montadert, L., Sancho, J., and Winnock, E., 1973. Northwestern Mediterranean sedimentary basins from seismic reflection profile: Am. Assoc. Petrol. Geol. Bull., v. 57, p. 2245-2262.

Miller, A. R., 1972. Deep convection in the Aegean Sea: Colloques Internat. du C.N.R.S., v. 215, p. 1-19.

Miller, A. R., 1972. Speculations concerning bottom circulation in the Mediterranean Sea: In Stanley, D. J. (Ed.),
The Mediterranean Sea: A natural sedimentation laboratory: Stroudsburg, Pa. (Dowden, Hutchinson and Ross, Inc.), p. 37-42.

Morgan, P., in press. Cyprus heat flow with comments on the thermal regime of the eastern Mediterranean: paper submitted for inclusion in the IUGG European Heat Flow Monograph.

Nason, R. D. and Lee, W. H. K., 1964. Heat-flow measurements in the North Atlantic, Caribbean, and Mediterranean: J. Geophys. Res., v. 69, p. 4875-4883.

Ratcliffe, E. H., 1960. The thermal conductivities of ocean sediments: J. Geophys. Res., v. 65, p. 1535-1541.

Ross, D. A. and Uchupi, E., in press. The structure and sedimentary history of the southeastern Mediterranean Sea-Nile Cone area: paper submitted to Am. Assoc. Petrol. Geologists Bull.

Ryan, W. B. F , 1969. The floor of the Mediterranean Sea. Part I: The structure and evolution of the basins: Ph.D. Thesis, Columbia University, N.Y.

Ryan, W. B. F., Hsü, K. J., et al., 1973. Mediterranean Ridge, Levantine Sea-Site 130. In Ryan, W. B. F., Hsü, K. J., et al. Initial Reports of the Deep Sea Drilling Project, Volume 13: Washington (U.S. Government Printing Office), p. 355-382.

Sancho, J., Letouzey, J., Biju-Duval, B., Courrier, P., Montadert, L., and Winnock, E., 1973. New data on the structure of the eastern Mediterranean basin from seismic reflection: Earth Planet. Sci. Lett., v. 18, p. 189-204.

Sclater, J. G., Jones, E. J. W. and Miller, S. P., 1970a. The relationship of heat flow, bottom topography, and basement relief in Peake and Freen deeps, northeast Atlantic: Tectonophysics, v. 10, p. 283-300.

Sclater, J. G., Mudie, J. D. and Harrison, C. G. A., 1970b. Detailed geophysical studies on the Hawaiian arch near $24^{\circ} 25^{\prime} \mathrm{N}, 157^{\circ} 40^{\prime} \mathrm{W}$ : A closely spaced suite of heat-flow stations: J. Geophys. Res., v. 75, p. 333-348.

Selig, F. and Wallick, G. C., 1966. Temperature distribution in salt domes and surrounding sediments: Geophysics, v. 31 , p. $346-361$.

Sleep, N., 1975. Stress and flow beneath island arcs: Geophys. J. Roy. Astron. Soc., v. 45, p. 827-857.

Stanley, D. J., McCoy, F. W. and Diester-Haass, L., 1974. Balearic abyssal plain: An example of modern basin plain deformation by salt tectonism: Marine Geol. v. 17, p. 183 200.

Storetvedt, K. M., 1973. Genesis of west Mediterranean basins: Earth Planet. Sci. Lett., v. 21, p. 22-28.

Vogt, P. R. and Higgs, R. H., 1969. An aeromagnetic survey of the eastern Mediterranean Sea and its interpretation: Earth Planet. Sci. Lett., v. 5, p. 439-448.

Von Herzen, R. P and Maxwell, A. E., 1959. The measurement of thermal conductivity of deep-sea sediments by a needle probe method: J. Geophys. Res., v. 64, p. $1557-$ 1563.

Von Herzen, R. P. and Uyeda, S., 1963. Heat flow through the eastern Pacific Ocean floor: J. Geophys. Res., v. 68, p. 4219-4250.

Von Herzen, R. P. and Lee, W. H. K., 1969. Heat flow in oceanic regions: In Hart, P. J. (Ed.), The Earth's crust and upper mantle, geophysical Monogr. No. 13: Washington (American Geophys. Union), p. 88-95.

Von Herzen, R. P., Hoskins, H. and Van Andel, T. H., 1972. Geophysical studies in the Angola diapir field: Geol. Soc. Am. Bull., v. 83, p. 1901-1910. 